Article

\title{
Business Lobbying: Mapping Policy Networks in Brazil in Mercosur
}

\author{
Galia J. Benítez \\ James Madison College, Michigan State University, East Lansing, MI 48825, USA; benitez6@msu.edu
}

Received: 16 August 2018; Accepted: 10 October 2018; Published: 15 October 2018

\begin{abstract}
In the creation of trade policy, business actors have the most influence in setting policy. This article identifies and explains variations in how economic interest groups use policy networks to affect trade policymaking. This article uses formal social network analysis (SNA) to explore the patterns of articulation or a policy network between the government and business at the national level within regional trade agreements. The empirical discussion herein focuses on Brazil and the setting of exceptions list to Mercosur's common external tariff. It specifically concentrates on the relations between the Brazilian executive branch and ten economic subsectors. The article finds that the patterns of articulation of these policy networks matter and that sectors with stronger ties to key government decision-makers have a structural advantage in influencing trade policy and obtaining and/or maintaining their desired, privileged trade policies, compared with sectors that are connected to government actors with weak decision-making power, but might have numerous and diversified connections. Therefore, sectors that have a strong pluralist-clientelist policy structure with connections to government actors with decision-making power have greater potential for achieving their target policies compared with more corporatist policy networks.
\end{abstract}

Keywords: organizational state framework; policy networks; regional trade agreements; Mercosur; Brazil; social network analysis

\section{Introduction}

The literature on interest groups and lobbying has extensively studied "whose voice gets heard" and unanimously concludes that groups have unequal amounts of power and influence in the political process (Grossmann 2012; Woll 2008; Magee et al. 1989). The influence of business groups or corporate actors on governments is undeniable; the news is filled with information regarding the power of these groups and the means they use to influence the government to act in their favor, even if that action is against the public interest. One particular policy domain where the power and influence of business is more evident is trade policy. ${ }^{1}$ The literature has demonstrated that corporate actors, compared with other societal groups, are more successful at lobbying, that is, navigating the politics within the government and its institutions to obtain protection of their interests over that of the public they are supposed to serve (Grossmann 2012; Krueger 1990; Lindblom 1977; Woll 2007). The trade literature has asked what drives the wedge between the economic optimality of free trade and the persistence of protectionism? "Politics" is Cohen's (Cohen 1990, p. 85) answer to this question. The study of politics has been challenging because of the difficulty of measuring the power and influence of interest groups and the deficiency of frameworks that consider both the co-influence of the state and interest

1 (Knoke and Laumann 1982, p. 256)) identify a policy domain as “ . . a substantively defined criterion of mutual relevance or common orientation among set of consequential actors concerned with formulating, advocating, and selecting courses of action (that is, policy options) that are intended to resolve the delimited substantive problem in question." 
groups in trade policymaking in political systems and institutional settings. Despite the importance of considering institutional settings, scant attention has been paid to countries where trade policy is implemented through the bureaucracy.

Most studies have attempted to analyze government-business relations based on congresses and developed nations, such as the United States (US); notably, literature that has investigated the European Union (EU) and their bureaucracies is emerging (Greenwood 2003). Trade policy in most Latin American countries is created exclusively through the executive branch, with limited oversight from their congresses. Even in countries where the legislature has a predominant role in creating trade policy, such as the United States, the president's office, and its trade advisory committees, have been gaining relevance in the last decades (Destler 1986; Moore 1992). Consequently, investigations into the role of the executive branch and its bureaucracy and interactions with interest groups in creating trade policy within a developing country and within less developed regional trade agreements (RTAs) are overdue, and this analysis aims to fill this gap by characterizing these relations as policy networks. Policy networks rely on the standard classification of business-government intermediation structures-clientelism, pluralism, and corporatism.

As Schneider (1992, p. 110) explains, policy networks can be understood as " ... the set of actors and the set (sometimes multiplex) links between the actors in policymaking". This definition allows for the study of politics, the possibility of empirically measuring the position and strength of links among actors using social network analysis (SNAs), and the conceptualization of power in relational terms. Pluralism and corporatism have been commonly explained under the macro distinction of weak and strong states vis-a-vis societal actors (Jordan and Schubert 1992). Under pluralism, states are often assumed to be weak compared with societal actors, whereas the contrary is true under corporatism - the state has substantial influence over societal actors. As Jordan and Schubert (1992) explained, although this macro-classification is crude and empirically inaccurate, countries are often fit into these categories regardless of the strength of their corporatism or pluralism traits.

This paper asserts that these traits are best explained at a sub-sectoral level, at an industry level, especially in developing nations where diverse development models with their particular means of organizing the state and government relations coexist at different degrees. The blurring of the boundaries between the government actors and the business sector is not the same across the board; the boundaries occur along sub-sectoral lines. Although, asserting that these lines are blurred is insufficient, and attention must be allocated to the degree across different domains, similar to the claims of Laumann and Knoke (1987) and within domains at specific events. ${ }^{2}$ Business groups' influence on policymaking depends, in part, on the strength of the historically established relations between the economic and government actors (e.g., prior channels of communication, personal connections). Therefore, framing government-societal links as policy networks goes to the heart of the explanations of policymaking by considering the countries' institutional setting and the government's decision venues; while allowing for the confluence of diverse political actors and politics by permitting the use of applied formal social network methods within a specific policy domain: trade policy. The advantage of this approach relies on uncovering the meso-structural aspects of interaction at the organizational level, allowing for a more refined comparison among the economic sub-sectors within and across countries (Comunello 2011; Schneider 1992).

This paper argues that government and business actors' interactions are intermediated by policy network structures that regulate the access and influence of economic actors in foreign trade policymaking, and these must be considered as a spectrum of private-public network classifications (Schneider 1992). This article explores how the intermediation structures among trade associations and the bureaucracy contribute to free trade deviations within specific RTAs. The discussion focuses

2 This is defined by (Laumann and Knoke 1987, p. 2)) as "a critical, temporally ordered decision point in a collective decision-making sequence that must occur in order for a policy option to be authoritatively selected". 
on Brazil and its participation in the southern common market (Mercosur). ${ }^{3}$ This article focuses on government-business intermediation structures within ten economic sub-sectors, and the trade holes or deviations from Mercosur's common external tariff (CET) that have been maintained beyond the agreed-upon period. ${ }^{4}$ These deviations have been performed by placing certain products onto a national exemption list or by the permanent change of tariff rates for a specific product line. Therefore, this article provides answers regarding who the main actors are and determines how these actors influence Mercosur's CETs.

For the Brazilian case within Mercosur, this paper found that sectors that form a strong pluralist-clientelist policy structure have greater potential for achieving their target policies compared with a strong corporatist policy network, despite that both are connected to government policy deciders. This phenomenon is the result of strong and direct pluralist-clientelist ties to the key decision-makers that provide a structural advantage in influencing trade policy-making and obtaining and/or maintaining their desired, privileged trade policies, compared with sectors with corporatist structure that may have diversified connections but are connected to government actors with weaker decision-making power. This paper does not claim that policy network alone explains CETs, but that close-tied networks enhance the opportunities and likelihood of the sectors to influence government policy decision-making. The argument here is based on the understanding that policymakers decide policy by mediating between the sector's interests, the country's economic policy concerns (i.e., foreign and domestic), and their organizational concerns.

There are several reasons that Brazil and its participation in Mercosur make an excellent case study. Mercosur is the third largest RTA in the world (\$2.9 tn) after North America Free Trade Area (NAFTA) and the EU, and intends to expand beyond its current boundaries to encompass all of South America. In addition, it is one of the few RTAs from the developing world that have engaged in a more profound integration schema as a common market, and it has expressed its commitment toward creating a political union. Mercosur is an excellent example of trade policy making within an intergovernmental arrangement within an RTA. Mercosur and CETs are also keys to exploring the relative feasibility of multilateral and regional agreements. Finally, a study of the CET deviations of Mercosur, and especially of Brazil, is central for exploring the domestic forces that could support or block liberalization in other arrangements. In Mercosur, tariffs have come down significantly but remain at an average of about 12 percent. However, this average tariff does not consider Mercosur's various CET exceptions that could reach 35 percent, the maximum allowed by the World Trade Organization (WTO). The ongoing persistence of tariff barriers, though at a much lower level, is still cause for study. The selection of Brazil is also important because the exemptions from Mercosur's CET are decided within each of the countries, making the study of their domestic forces key to understanding the politics of CET within Mercosur.

Brazil is the lead member of the group, and thus plays a crucial role in the decision-making process. As Olarreaga and Soloaga (1998, p. 30) observed, this country has “important weight in Mercosur's tariff structure, given Brazil's significant share of Mercosur's production and the intergovernmental aspect of the decision-making process". Mercosur's policies and their success are, therefore, primarily determined by Brazil, which has defined Mercosur partner countries' perceptions of the cost and benefits of integrating. Brazil accounts for 70 percent of this groups' production, of the entire Mercosur sector. Its participation in the world economy reinforces Brazil's importance. Mercosur as a group is the world's fifth largest economy, with many of the largest firms in Latin America, and is increasingly engaged in trade and outward foreign direct investment within and beyond South America. Also,

3 Mercosur, created on 26 March 1991, has four founding members—Brazil, Argentina, Uruguay, and Paraguay-plus its newest member, Venezuela.

4 The CET is an import tax calculated as a percentage of imported goods and equally levied for each type of good for all member countries. Mercosur has 11 tariff levels that vary from $0 \%$ to 20\%, with intervals of two percentage points, and 9791 tariff lines. The time range of these deviations can range from six months to years and, in a few cases, decades. 
because of the size of its economy and its industries, Brazil presents significant variations across sectors, making it an ideal case. Consequently, Mercosur and the study of CETs within Brazil present a rich case for exploring domestic forces within RTAs.

\subsection{Lietrature Review: Trade Policy Making and Economic Sectors Lobbying}

Businesses enjoy a privileged position in the creation of trade policy. Notably, we must be cautious not to overstate the power of the business sector vis-a-vis the government. The government should not be considered an empty vessel where interest groups interact but as crucial actors within the state-market condominium (Underhill 2000). It is insufficient to only investigate the demand side of trade policy (e.g., the interest groups), as the bulk of U.S. trade literature has done; the supply of policymaking (i.e., the government) must also be examined. Societal and government forces have their own interests and agendas that must be considered in the analysis. The bulk of trade literature has investigated the United States and its legislative branch while excluding the executive branch and their agencies. Other bodies of literature must be examined to analyze trade policy through the executive side, such as those that have investigated the role of bureaucracy in trade policy, comparative lobbying, and interest groups intermediation of policy networks (e.g., the European case). The EU trade literature mostly deals with business bargaining power at a supranational level (i.e., the European Commission). Greenwood (2003) explains that multilevel institutions such as the EU supranational institutions provide interest groups with diverse points of contact. The comparative literature contrasts the U.S. bottom up, where interest groups drive the process to the EU top-down approach, in which the European Commission is the main venue for trade policymaking (Broscheid and Coen 2003; Dür 2008; Eckhardt 2015; Shaffer 2003; Tsebelis 2002; Van den Hoven 2002; Woll 2006; Woolcock 2005). However, there is also another important avenue through the members' States and from here to the Council of Ministers. Young (Young 2004) argues that a business with a protectionist agenda that targets their State is more successful that sectors that have to go through supranational institutions. Mercosur is an example closer to this first option as it deals with matters of trade using an intergovernmental arrangement and not through supranational institutions. There has been rich literature that studies interest groups within NAFTA, and the majority have concentrated on the power and influence of business in the legislative side (Chase 2003) and labor (Kay 2011, 2015).

The U.S. endogenous trade literature analyzes the demand side of protectionism and studies import barriers by determining the influences of the private sector on setting tariff levels based on the companies' characteristics (e.g., industries' geographic concentration, size, use of intensive and less-skilled labor, and the share of the industry gross domestic product (GDP) (Godek 1985; Marvel and Ray 1983; Olarreaga and Soloaga 1998; Pincus 1975; Saunders 1980; Trefler 1993). Therefore, restrictions on trade are considered the result of interest groups seeking rents from the government (Magee et al. 1989; Nelson 1988). In this literature, power is not considered relational but inherent to the actor. Additionally, this literature excludes the countries' institutional system or structure of relations, which this article considers. The U.S. endogenous trade literature that studies the supply side of protectionism emphasizes the role of the government as an active participant and concludes that the government is the supplier of protectionism. This rich literature combines both actors: government and business. Empirically, the supply side has been conceived based on officials maximizing the country's national welfare first, and their utility second. The former approach is based on the legitimization that state actors receive from national constituencies in their quest for comprehensive social goals that maximize the national welfare of a country, called the "benevolent dictator" by Moore (1990, p. 147). The literature on the latter characterizes these officials as vote-seeking politicians motivated by their desire to remain in office. Considering these goals, the government officials attempt to manage the political pressure for and against protectionism. Although this literature is helpful to understand the legislative side and characteristics of the industries, in the case of Brazil, the lack of data and consideration of the political venue for setting CETs limits this literature. This paper 
focuses on understanding the preferences these groups have regarding trade policies, and the intensity of these links to the government by considering the country's bureaucracy power.

To understand Brazil's trade policy, the role of bureaucracy is essential. As Moore (1992) claims, even in developed countries, trade protection begins in bureaucratically-implemented administrative procedures. Despite their importance, the studies of bureaucracies on trade have been modest within the United States; exceptions include Rosenbaum (1999) and Destler (2015). This literature discussion has focused on the bureaucracy's need for expertise and to protect themselves, namely, avoiding influence from private groups (Rosenbaum 1999). Undoubtedly, this phenomenon is a challenge that bureaucracies must manage when interacting with the business sector.

Another significant body of literature is from comparative interest groups and concentrates on interest intermediation, that is, the study and characterization of the interrelations of the state and interest groups. The literature examining these links has focused on the strength of the state vis-a-vis societal groups and conceptualized those interrelations as a network, although mostly metaphorically. As this diverse literature has indicated the importance of framing the relationship between states and interest groups as a network, why not treat it as such and use SNAs for systematizing and comparing these types of networks, as this paper has done. In the last three decades, efforts have been made to refine the concept of networks, and many studies have proposed various characterizations based on the pluralist-corporatism dichotomy and network typologies. This literature can be loosely classified into two approaches. The first considers close relations suspicious; is currently less supported (i.e., capture and iron triangles (Bhagwati 1982; Destler 2015; Rosenbaum 1999)); and explains that businesses pressure the government to extract rents, causing them to deviate from their most efficient and socially optimal use (Bhagwati 1982). The second adopted perspective argues that the relationship between government and business could also be positive (O'Toole 1988). This paper relies on a subset of this latter literature that focuses on the concept of policy networks from the intermediation school.

The majority of policy network literature that studies economic sectors or industries has most commonly used inter-organizational approaches; notably, this paper also subscribes to these approaches (Borzel 1998). The concept of policy networks refers to a "Babylonian variety" of methods and meanings (Borzel 1998, p. 253). Policy networks' configurations describe an array of arrangements-iron triangle, issue networks, policy community, state corporatism, societal corporatism, clientelism, group sub-government, and so forth (Freeman and Stevens 1987; Haas 1992; Heclo 1978; Richardson and Jordan 1979). Therefore, to avoid introducing new terms and confusion, this paper adopts a narrower definition of policy networks that allows the use of formal SNAs and graph theory to examine the properties of the network proposed by Schneider (1992).

\subsection{Framework: Understanding Interest Group-Business Policy Networks}

The proposed framework builds on Schneider's Schneider (1992) classification of policy networks (e.g., pluralist, corporatist, and clientelist network) and considers the connection of the sectors to critical governmental policy makers. For Schneider (1992), first, a pluralist network links pluralized political, societal organizations with a fragmented and equally pluralized government sector. In this type of structure, pluralist actors can use communication channels to influence the government directly or through intermediary associations. Because individual actors can use intermediary organizations, they do not have as prominent a strategic role as they have in corporatism. Second, clientelist networks are predominantly formed by a relationship between strong patrons and weak clients. Clients compete for scarce resources and access to obtain a privilege or benefits. The relationship between clients and groups are dyadic, and clients participate directly without mediating groups. Because of these close relations, the risk of clientelism is that the business sector can co-opt the government. Third, the corporatist policy network describes a specific system of interest representation that encompasses intermediary organizations that occupy a brokerage position, that is, they have a representation oligopoly. Therefore, because these organizations do not compete with each other, they gain a strategic position in the policy network, where they exert monitoring and control capacities. These three systems 
of interest representation are complementary because groups apply these strategies when interacting with the government. Therefore, these policy networks are non-mutually exclusive structures, as the literature on weak and strong states wants us to believe. Adding to this explanation is the importance of the links with key decisional actors and the intensity of the links. Not all actors are the same, and the venue selection for lobbying is essential. Economic sectors organizations have limited resources (e.g., time, money) and are facing constraints from their environment (e.g., lobbying rules, scare time of bureaucrats, senators or congressional representatives, historical links). Therefore, to affect policy interest groups, choose the best government venue to maximize their chances to get their desire policy through. The strong policy networks are interest groups that are well connected to crucial government actors, the 'deciders', and occupy a strategic position within the policy network. On the contrary, weak policy networks are formed between interest groups and less powerful government actors (See Figure 1). The direct access to government policymaker 'deciders' potentially enhanced the possibility of the sectors to influence the government received protection or pushed their agenda.

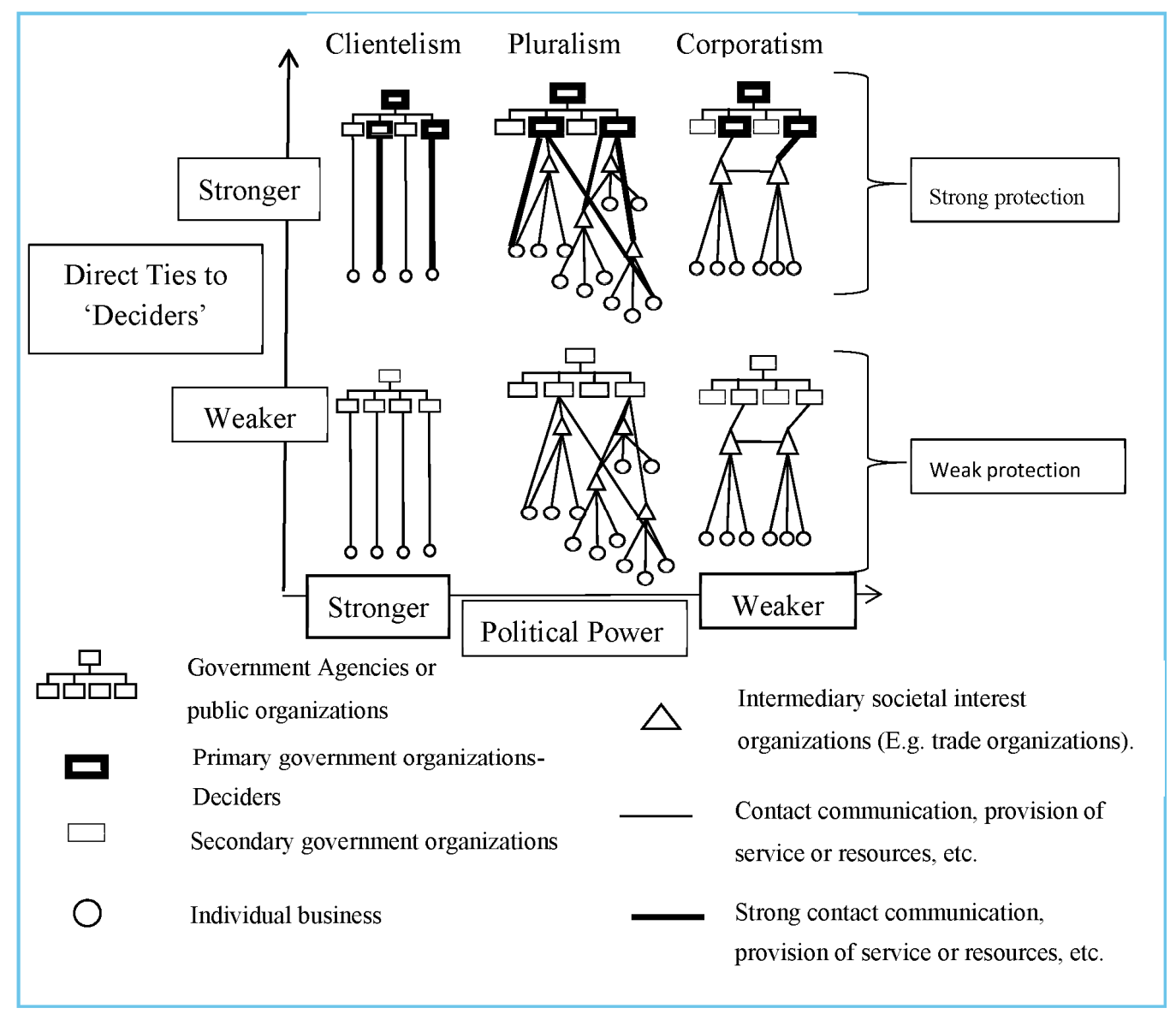

Figure 1. Policy networks structures (framework modified from Schneider (1992)).

\subsection{Background: Brazil Trade Policy and Interest Groups Organizations}

In Brazil, the executive branch is charged with negotiating all the early details of trade agreements, and it is responsible for implementing the terms of the agreement, once Congress approves the treaty. The bureaucracy is responsible for discussing and negotiating with domestic societal actors internally and other nations externally. The legislative power, by contrast, mainly participates in making trade policy at the final stage of the negotiating process by approving these trade agreements after the executive branch has formulated them. Therefore, because the motive of policymakers in charge of trade policy is not re-election, the strategies that advocacy groups use are modified, compared with lobbying the legislative side. Instead of focusing on maximizing their resources to help re-elect 
policymakers, they must contribute to nonelected officials by providing technical information, data, and research (Mahoney 2008).

Brazil has no overall trade law or unified entity that implements trade policy. Trade policy law encompasses numerous laws, decrees, resolutions, and ministerial acts that involve many entities. Keedi (2007) argues that more than 320 organizations are spread across the ministries responsible for trade issues. Under this configuration, authority is dissipated, and these actors formed a network. Given the complexity of any government, and especially trade policy creation within Brazil, the first question should be, what body has jurisdiction to take decisive action on trade policy? (Alt and Gilliga 1994).

In the case of Mercosur, the setting of CETs within Brazil belongs to the Chamber for Foreign Trade (CAMEX), part of the Government Council under the president. CAMEX is the Brazilian organization that formulates, adopts, implements, and coordinates the foreign trade policy of goods and services, that is, regarding Mercosur and all international negotiations and trade processes. CAMEX could be compared with the U.S. trade policy advisory committee. Although, CAMEX is more powerful because instead of being only an advisory board, this organization has the power to make decisions. CAMEX is a notable example of an intergovernmental network where diverse hierarchical ministries connect in a horizontal manner (Agranoff 2007). O'Toole (1988, p. 418) defines these arrangements as "all or part of multiple organizations where one unit is not merely the formal subordinate of the other in some larger hierarchical arrangement". Networks create complexity and challenges for decision-making compared with more hierarchical arrangements (Agranoff and McGuire 1998). CAMEX comprises seven permanent ministries (e.g., Development, Industry, and External Trade (MDIC); the Civil House (CC); the Ministry of External Relations (Itamaraty); the Ministry of Finance and Treasury (MF); the Ministry of Agriculture, Cattle, and Supply (MAPA); and the Ministry of Agrarian Development (MDA) (See Figure 2). These ministries are congregated in the Council of Ministries, which is the CAMEX's superior deliberative and final body that defines directions and procedures relative to foreign trade policy while coordinating and orienting the bodies in charge of trade policy. Other government organizations might be invited to participate if the topics discussed are of concern to them. In addition, the CAMEX is integrated by four bodies that serve as support (i.e., the Executive Management Committee-GECEX, the Committee of Financing and Guarantee of Exports-COFIG, an Executive Secretary-SE, and the Consultative Council of the Private Sector-CONEX). The role of the private sector through the CONEX, a private sector advisory committee, is irrelevant; in interviews with the industries' representatives, they did not initially recall this organization.

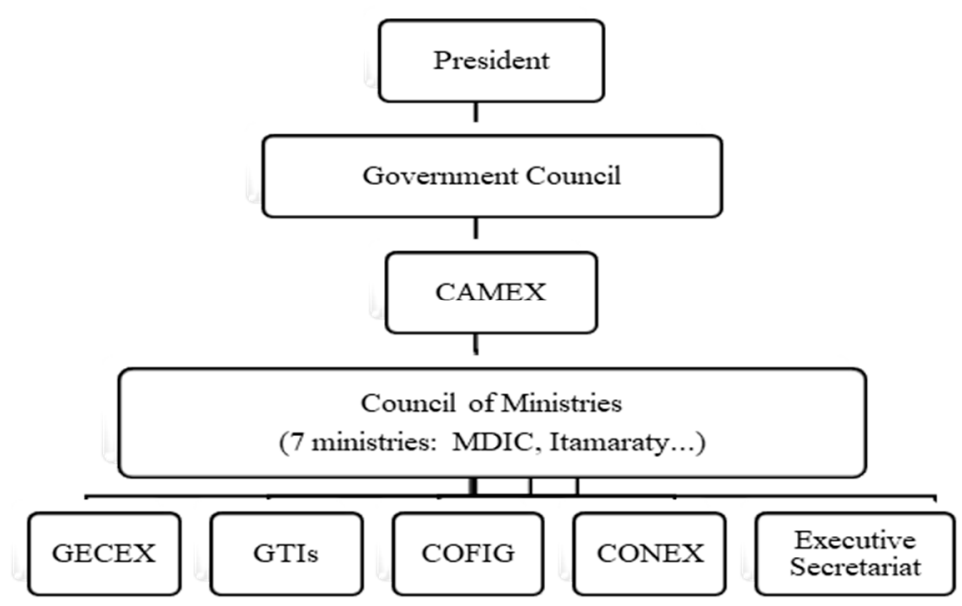

Figure 2. Brazil's trade policy institutions: Chamber for Foreign Trade (CAMEX) organogram. GECEX - the Executive Management Committee; GTI- The Interministerial Groups; COFIG-the Committee of Financing and Guarantee of Exports; CONEX-the Consultative Council of the Private Sector-CONEX; MDIC-Development, Industry, and External Trade. 
Business sectors lobby government actors through their associations and individual contacts to affect CETs. As a legacy of the corporatist state that had existed in Brazil since the Estado Novo of Getulio Vargas, the industrial sectors organize into multilevel government-mandated associations. This government-mandated representation structure could be depicted as a pyramid, where at the local level, multiple individual companies congregate into local business unions also associated with their respective regional associations. These regional associations, together with other industry-specific national associations, are congregated into one peak association (Figure 3). By law, all industries are required to pay a mandatory syndical tax, but are not required to be associated (Pinto 2001).

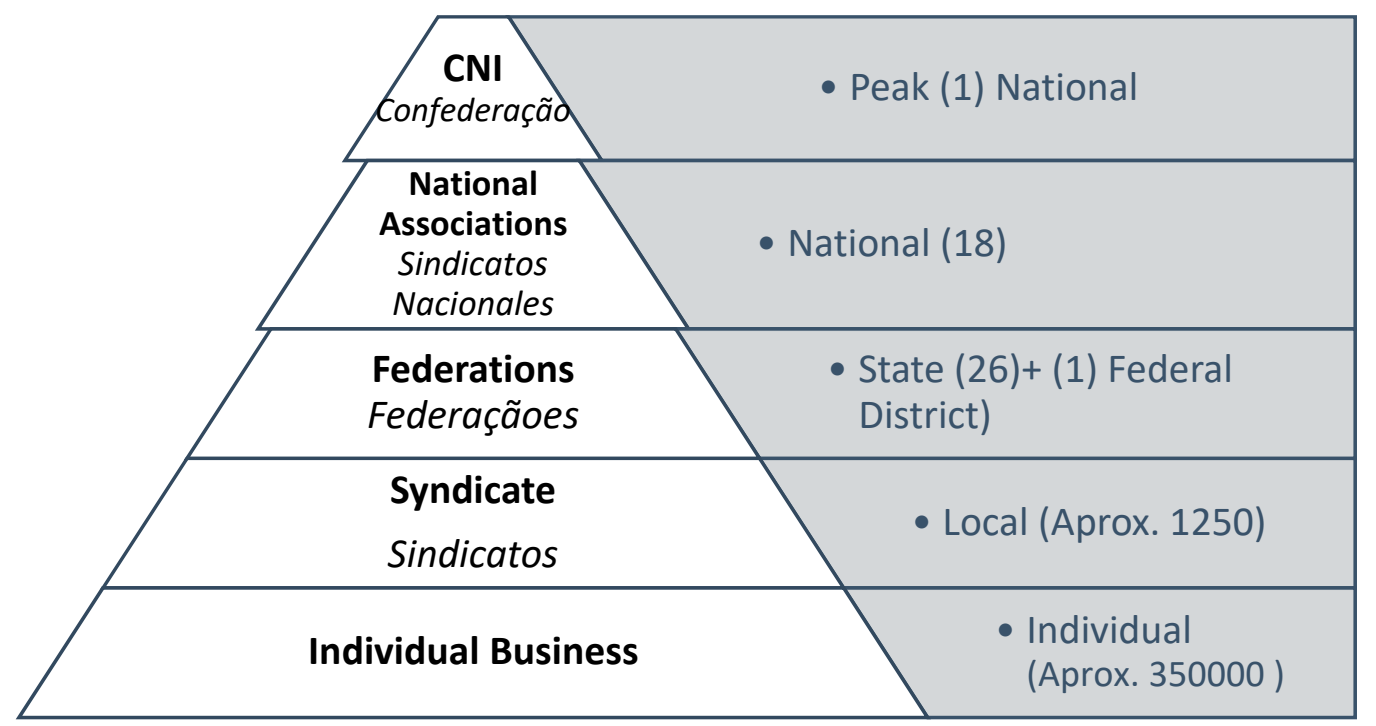

Figure 3. Structure of Government-Mandated Business Associations. CNI—the Confederação Nacional da Indústria.

At the top is the Confederação Nacional da Indústria (CNI), Brazil's umbrella association for the industrial sector. At the national level, selected industries combine into 18 associations-Sindicatos Nacionales. At the state level, there are 27 businesses federations, or federaçães, one for each state. At the local level, there are more than 1000 Sindicatos from different sectors that aggregate approximately 300,000 individual businesses. The producers in the agriculture sectors are also organized in a structure that mirrors organizations in the industry sector. The agriculture sector umbrella association is the Confederação da Agricultura e Pecuária do Brasil (CNA). This research, however, does not consider this association, because the CNA mainly represents smaller scale agro producers at the rural level. The CNI represents the agroindustry with large-scale production and exporters.

The pyramidal participatory arrangement has discouraged active participation. For instance, out of the 100 sectors within the economy, only 18 managed to create nationally specific associations, most founded during the 1960s and 1970s. These associations represent diverse sectors such as beer, auto parts, vehicles, rubber, and machinery. The main structure of these mandatory organizations was maintained until the mid-1980s and 1990s when the political environment began transforming into a more liberal system. The different sectors started pressuring their federations and syndicates to change, modernize, and become more responsive, but problems remained. Because class associations are industry-specific and more efficient than the prior compulsory associations, the different sectors in matters related to CET use these associations to influence the government. Notably, many of the mandated associations share the same headquarters, staff, and websites with their voluntary counterpart associations. 


\section{Data and Method}

This paper adopts a nominalist approach on social reality to determine the specific policy domain boundary (Laumann et al. 1992). Specifically, the definition of the network boundaries in this research was developed by first selecting formally constituted groups such as business associations and their individual companies' members that were key in setting CETs, and then determining key governmental organizations in charge of foreign trade policy during Luis Inacio da Silva's second government term, from 2007-2011.

Actors here are considered, as the organizational state framework explains, corporate entities engaged in policymaking. Individual corporations or firms are important only if they act on behalf of their organization (Laumann et al. 1985). Within trade policymaking, the benefits gained by an increase or decrease of a particular CET affects the whole subsector and not just a particular corporation or individual firm. Thus, even if companies are lobbying individually for a specific firm, the benefits are shared by the other members of the subsector. In addition, the state is not considered as a unitary actor, but as a collection of bureaucratic organizations. Ten voluntary associations from diverse industries were selected from within the economic subsectors. Table 1 summarizes the sectors and their respective associations, from agriculture to manufacturing, of differing sizes and importance to the Brazilian economy, providing enough variation to compare their network formations and influence in the government.

Table 1. Selected Associations.

\begin{tabular}{ccc}
\hline & Sub-Sectors & Trade Association \\
\hline 1 & Wheat Mill & ABITRIGO \\
2 & Soy & ABIOVE \\
3 & Textile and Apparel & ABIT \\
4 & Footwear & ABICALÇADOS \\
5 & Motor vehicles & ANFAVEA \\
6 & Auto parts & ABIPEÇAS \\
7 & Sugarcane \& Alcohol & UNICA \\
8 & Swine Meat & ABIPECS \\
9 & Poultry Meat & ABEF \\
10 & Bovine Meat & ABIEC \\
\hline
\end{tabular}

These actors and the specifications of their network boundaries were selected by adopting the following strategies: (1) matching the 9791 product lines of Mercosur's CET and the 100 product lines of the Brazilian CET's exceptions list with specific industries (e.g., wheat, sugarcane); (2) linking the selected industries with their representative business associations (e.g., wheat is represented by ABITRIGO); (3) matching the business associations with their corresponding CET code, identified by their direct contact with the government (e.g., ABITRIGO is concerned with 31 product line codes for the wheat sector); and (4) identifying the individual companies associated with these specific trade organizations.

Figure 4 explains how these business associations were selected. For instance, ABITRIGO, the association for the wheat mills industry, was selected by collecting their 31 corresponding product code lines, which range from $11,010,010$ to $11,090,000$. Products that form part of a chain of production, and products that are difficult to link to one specific economic sector or make a direct connection with a particular trade association, were not considered. For instance, steel, an input in many industries, was not selected. Government-mandated business associations organized at different levels were also selected (e.g., at the peak, national, and local levels). 

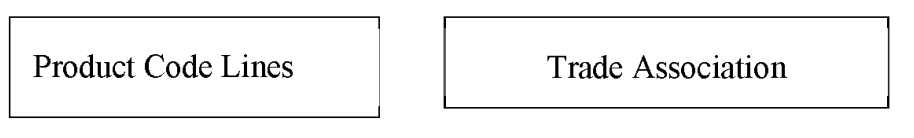

\section{Common External Tariff \\ (For each code line)}

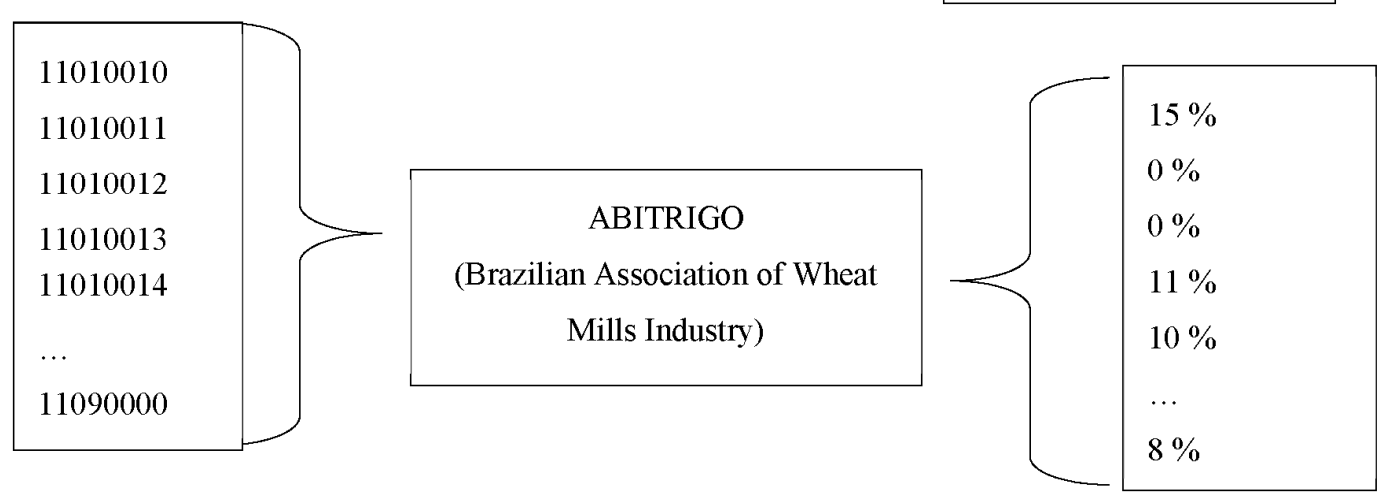

Figure 4. Method used for the selection of key sectors and their corresponding business associations.

Businesses membership information was mostly obtained through associations' websites, direct contact through phone and email, and purchasing a few firms' directories. The information on trade associations at the peak and federal levels was easy to find through their websites. Information at the state and firm levels mostly required direct contact by phone and email. The choice of the state actors was made by considering the organizational venues for creating trade policy within the Brazilian executive branch; specifically, the CAMEX, the organizations in charge of foreign trade and establishing CETs, and the president. In addition to studying the interactions of business groups with the president, this research examines the links between the three central ministries that form part of the CAMEX's superior deliberative and final body, the Council of Ministries (Conselho de Ministros-CM); the Ministry of Development (MDIC), which presides over the Council; the Civil House of the presidency; and the Ministry of Finance and Treasury.

The power of these agencies was determined through semi-structured interviews (for a list of all actors interviewed, see Appendix A, Tables A1-A5), including asking questions of the heads of the central governmental units in charge of trade, and actors from the economic subsectors, for example: Who are the most powerful government organizations in matters of trade? Whose opinion counts the most in the decision-making process in setting CETs? When companies want to change CET levels, whom do they contact first? Their answers were codified into three categories, namely, the most powerful, some power, and less powerful, which were codified as 3,2, and 1, respectively. The coding of the government, individual companies, and associations' semi-structured interviews were done in the original language, Portuguese, and occasionally in Spanish or English, where only the quotes used in the text were translated into English, these were divided into diverse codes selected beforehand that account for government power and industries channels of participation and influence.

These private and public actors' interviews were complemented by the number of times the companies and business associations met formally with these government actors, using data collected from the daily ministry agenda records. The agenda records for the president and the minister of CC were publicly available through the official websites, whereas the agendas for the ministers from the MDIC and MF had to be formally requested. Each of these government actors was mapped as an ego-network, a focal point that all the other associations and companies connect to. This information was also complemented with newspaper reviews.

Once the boundaries and the actors within the network were selected, the SNAs centrality measures were used to determine these actors' positions within each of the ego networks. Five thousand-four hundred nodes form the studied network. The actor sets encompass individual companies, government ministries, and business associations-voluntary as well as compulsory. These ties are measured in the following way: (1) affiliation networks (i.e., individual companies and their connection with peak, voluntary, and compulsory associations) and (2) influence network 
(i.e., individual companies, associations connections with government actors). The data were originally gathered as an edge-list and then imported to UCINET version 6.289 for Windows. To determine these actors' possible influences, this research used Freeman's degree and eigenvectors centrality. Degree centrality is the simplest measure of actors' centrality, which Freeman (1979) defines as the number of adjacent links on a node, and counts direct connections and accounts for specific targets. Degree centrality is used to determine the position these actors have within the network and contributes to the resources and access to policymaking these actors have. Eigenvector centrality considers the centrality of their node neighbors, that is, node centrality is proportional to the centrality of the nodes that are connected to it. These are localized measures because they provide information on the immediate network of a specific node. In addition, the links between government actors and those in the economic sector were mapped using structural variables, which measure specific types of ties between two actors. The strength of business ties with the government was measured in direct (geodesic distance $=1$ ) and indirect ties (geodesic distance $=2$ ). These measurements estimate the relations of political adjacency matrices that identify the number of paths of length that are between two nodes.

\section{Limitations}

The study of the executive branch is limited because we do not have records of actors voting for or against a specific policy. We are also missing the connection between campaign contributions and voting, which has been vital in the studies of the legislative branch; consequently, this makes the study of the interrelations between the bureaucracy and business sectors more obscure and difficult to measure efficiently and accurately. Moreover, in Latin America, the information about groups' access and influence in trade matters is not readily available or not collected. In the case of Brazil, making matters more difficult, information that was once public is no longer public when the president leaves office. In addition, Brazil does not delineate lobbying regulations, making an investigation more challenging. Presently, numerous bills are before Congress; therefore, under this context, in many instances, lobbying is equated to corruption (Fiuza 2002), adding obvious difficulties in researching this critical topic.

Despite this limitation, meetings can be used as a satisfactory proxy for measuring the access private sectors have to the government, which can be interpreted as the potential these sectors have to influence these policymaking actors. Access gives these private actors the possibility to inform themselves regarding government preferences and gives them the platform to express their own preferences and concerns. In the same manner, the membership of individual companies in trade associations gives them the opportunity to access sectors that may influence the government by using different channels.

Regarding government actors, not all ministries were included-the Itamaraty, MAPA, and MDA were not considered because the data were not publicly available. Notably, interviews were conducted with representatives of these ministries, during which they indicated that these government actors are contacted by many firms; however, most of the meetings are related to domestic matters, and many of the concerns about foreign matter refer to nontariff items, which is outside the scope of this paper. Another omission in the data collected is that the meetings for the studied ministries and the president are only those within the official agenda. Therefore, there were unreported meetings. Despite these limitations, the data is useful because the meetings for the government actors most active in trade policy were obtained, which serve as a good proxy to measure business access to governments.

\section{Results and Discussion}

This section first explains the key governmental actors in matters of CET, 'the deciders', and then characterizes the diverse government-interest groups' policy networks. 


\subsection{Key Governmental Actors}

According to government policy, all CAMEX permanent ministries have equal decision-making power, although the application of centrality measures and interviews of ministries' representatives have revealed that, in practice, these government actors do not participate equally in making trade policy. The position of these ministries within the network helps identify the influential venues in setting CETs. The descriptive statistics in Table 2 apply to the whole network and show the number of government links.

Table 2. Government actors Freeman degree centrality.

\begin{tabular}{cccc}
\hline Government Actors & Degree & \multicolumn{2}{c}{ Descriptive Statistics } \\
\hline MDIC & 159 & Mean & 6.199 \\
PRESIDENT & 69 & Std Dev & 15.881 \\
MF & 20 & Min & 1 \\
CC & 6 & Max & 159 \\
\hline
\end{tabular}

Note: MDIC - the Ministry of Development; MF-the Ministry of Finance and Treasury; CC—-the Civil House.

Of all the ministries that participate within the CAMEX, the MDIC is the most influential node with the highest degree centrality within the trade policy network (159). The prominent position of the MDIC is unsurprising because this ministry presides over the CAMEX and is the president of the Council of Ministries (CM) and the GECEX; the former is the most important body within the CAMEX with decision-making power. The GECEX, although relatively less powerful than the CM, is important because it serves as a support body, wherein technical matters are analyzed and discussed, and their results are later presented for approval at the CM level. The MDIC, therefore, has the power to participate in decision-making at different levels and in setting and controlling the agenda. These powers are further enhanced by the CAMEX's absence of an independent location, budget, and staff. Moreover, the MDIC houses the CAMEX and provides its staff and other material needs. The dependency of the CAMEX on the MDIC provides this ministry privileged access to individuals and information that other ministries do not have. Therefore, actors connected to this ministry are assumed to have the highest number of opportunities to influence policy and be informed regarding changes in this policy faster than other sectors. These connections are not just particular to trade policy, and interest groups already use these existing channels and connections to affect different policies.

Another critical ministry is the Finance Ministry, although less important in matters of trade compared with the MDIC; especially, compared with the whole network's mean degree centrality (6.2), the MF is influential (20-degree centrality). As one interviewer stated, "The power of the MF is undeniable, it is the ministry that controls the money." Its power is enhanced by its role in setting macroeconomic policies that profoundly influence trade. An example is the Plan Real, a government economic program developed during the 1990s to control inflation, which forced unilateral foreign tariff cuts. In addition, the importance of this ministry is also based on the technical knowledge and skills of its staff members, who serve as consultants on many trade issues and are concerned with how specific tariffs affect macroeconomic stability. These two ministries are heavily involved in international trade technical minutiae. The Itamaraty Foreign Relations Ministry, although important, is much more concerned with the international legalities of the treaties. In the interviews, the business groups repeatedly reported that their main points of contact in matters of trade are the MDIC and MF because of the Itamaraty's isolationist culture and strong diplomatic culture, which is not conducive to establishing an open dialogue. Surveys conducted in 2001 and 2008 on Brazil's international relations and the role of the Itamaraty found the following, "What is surprising is the general perception that the Ministry of Foreign Relations gives scant attention to opinions and proposals of third parties, even other ministries in the Federal Government." (Kunzler 2002, p. 103). In responding to this claim, the Itamaraty asserted that the problem is the business sectors' insufficient knowledge navigating diplomacy. This ministry was not included in the analysis because they did 
not provide information despite official requests to access the data on the ministry's contacts with the private sector. Although, interviews with their representative confirmed this sentiment. Notably, studies have argued that the influence of the Itamaraty in foreign policy has declined because of democratization and presidentialism in foreign policy (Cason and Power 2009).

The Civil House under the office of the presidency can be considered the Ministry of State in charge of all presidential matters that involve the Congress and governors. This government agency focuses on domestic matters; consequently, they have limited involvement with foreign trade. This conclusion is supported by the centrality measures (six-degree centrality) and interviews with government bureaucrats, business associations, and companies. Based on its degree centrality, this actor occupies the same structural position as the average actor in the network, that is, their influence in matters related to CETs is not strong. The final participant in trade matters is the president. After the MDIC, the president occupies a key position within the network (69-degree centrality). The president has the power to appoint the CAMEX's executive secretary, giving him direct access to policymaking procedures. In addition, the Civil House forms a part of the presidency, increasing the president's ability to intervene and influence the process. Although the president only occasionally attended the Council Meetings in person, he has intervened on behalf of various sectors, as the interviews suggested. We assume that the president's position as head of state ensures access to any organization and person, that is, the president's power is indisputable. In matters of trade, if interest groups in Brazil want to influence trade policy, they will need to target two main organizations: the MDIC and the MF.

\subsection{Business-Government Policy Networks}

\subsubsection{Pluralist Networks}

The motor vehicle, sugar/bioethanol, and footwear sectors access the government through a strong pluralist policy network with some clientelist ties, where individual companies and voluntary and compulsory associations have access to key government actors. The motor vehicle sector enjoys a maximum tariff of 35 percent permitted by the WTO (See Figure 5) and is the only sector outside of Mercosur CET. The remaining sectors are on the general CETs exemption list. In contrast with this sector, the sugar/bioethanol sector has strongly lobbied the government to lower their trade tariffs and were able to successfully influence the government to reduce the biofuel tariff from 20 percent to 0 percent, despite the Brazilian government's initial strong opposition. In 2017, this tariff was reverted with strong support from the sector because of the increase of U.S. imports by 320 percent. In addition, the footwear sector is outside of the CET, and is well-protected with a CET of 35 percent.

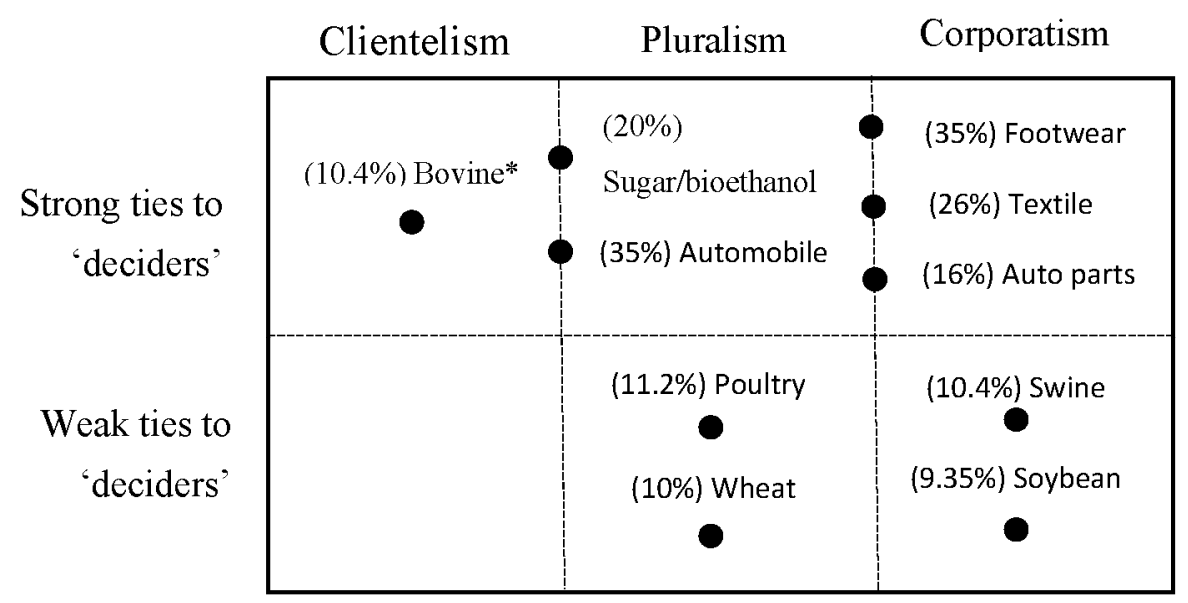

Note: *This sector is more affected by non-tariff barriers.

Figure 5. Common external tariff deviations and business associations matrix. 
The motor vehicle sector is the best-connected sector within this trade policy network (69-degree centrality; Tables A1-A4) and strongly connected to all decider government actors (Figures 6-9). Its pluralist policy network is formed by its voluntary association, ANFAVEA, which is directly connected to the MDIC (Figure 6 and Table A1), a key decider in trade policy, and other ministries such as the president, MF, and CC (represented in the graph by the thickness of ties; see Figures 7-9). In addition, the motor vehicle sector has strong clientelist links through which individual companies connect directly to the government: 16 individual companies met with the MDIC, 13 with the president, 2 with the MF, and 1 with the CC. This sector also forms part of compulsory business associations at various levels, including the industrial peak association (CNI), national associations (SINFAVEA), and state-level federations organized geographically (e.g., the powerful federations of the FIESP from São Paulo and FIRJAN from Rio de Janeiro). For instance, the CNI has access to all the ministries, and the FIESP also met with the MDIC, the president, and the MF. Primarily, the involvement of peak and federal associations in trade matters is limited because they represent many sectors and issues. Notably, in the case of Brazil, voluntary associations are more powerful when compared with compulsory association. The motor vehicle industry has the highest number of indirect ties (Table A4) to the MDIC, MF, and president. The eigenvector centrality supports the results given by degree centrality and refines them (Table A4). This measurement is helpful for mapping which political actors have more access to actors that are more influential than they are. Sectors such as sugar/alcohol and automotive connect to well-connected actors. The eigenvector centrality also indicates the difference in ties between these two prior actors and the remaining sectors. This sector's connection to the MDIC is almost three times that of the footwear or textile sectors.

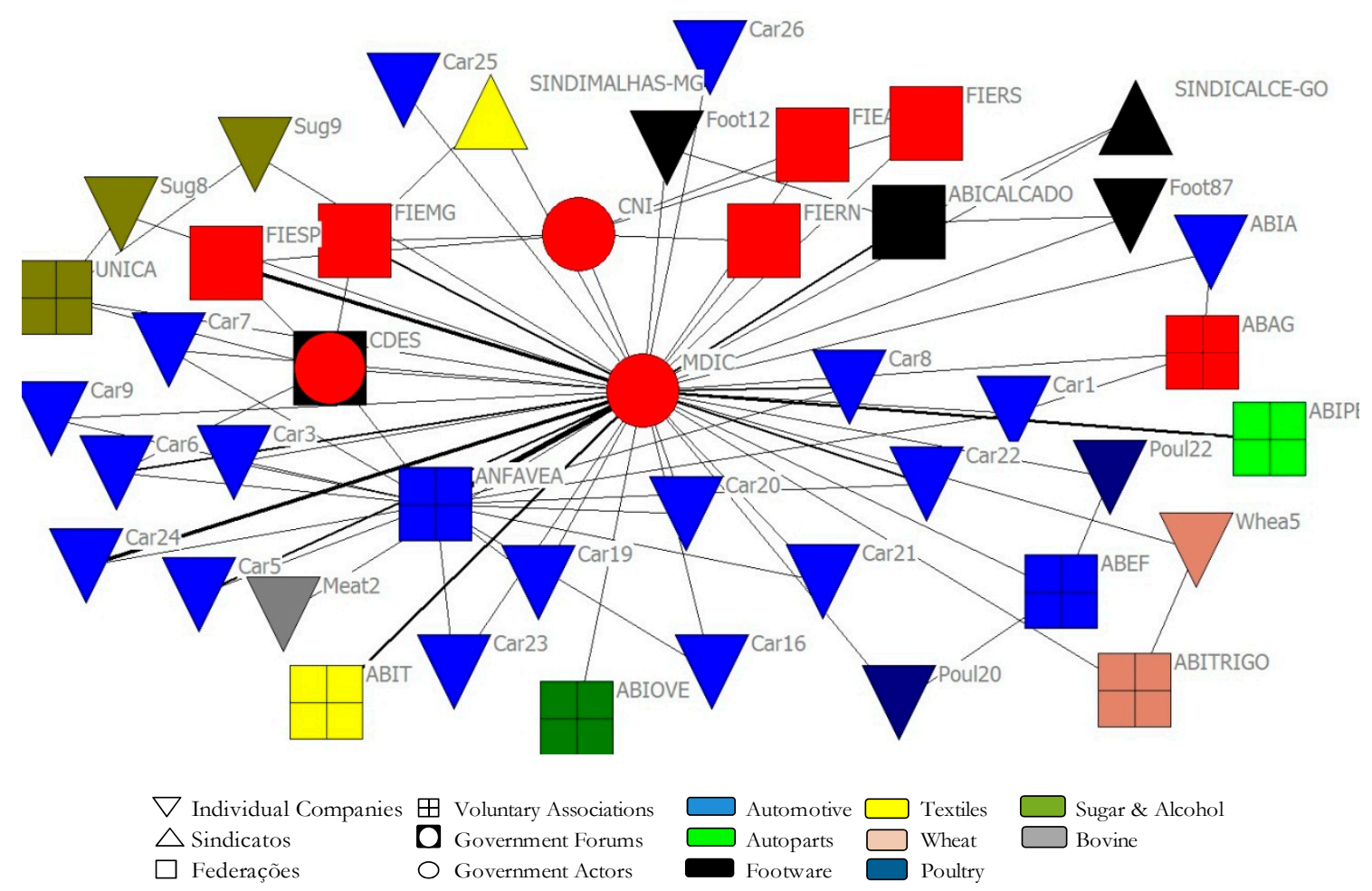

Figure 6. Direct ties among the Ministry of Development (MDIC), business associations, and companies (geodesic distance $=1$ ). 


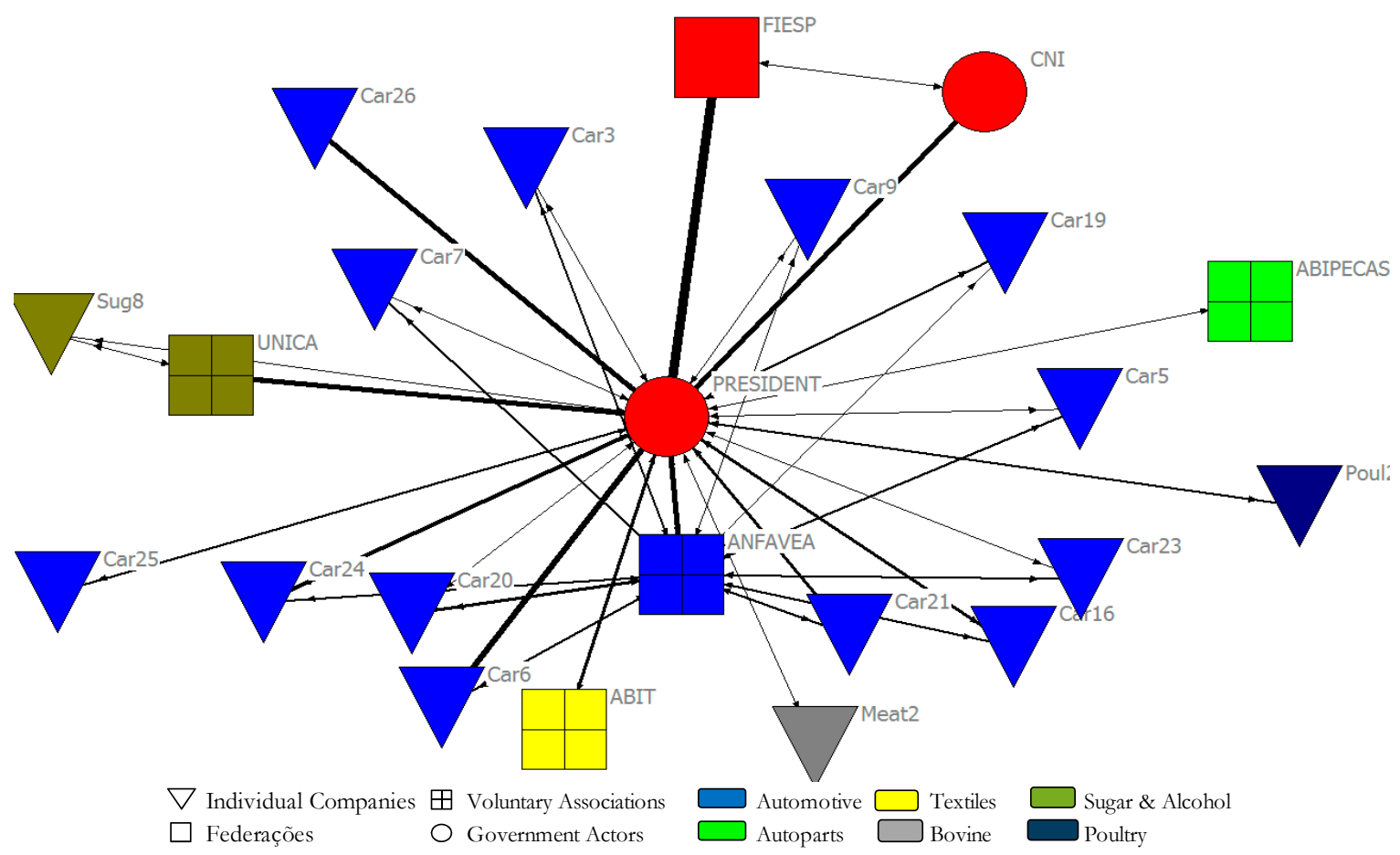

Figure 7. President's direct ties (geodesic distance $=1$ ).
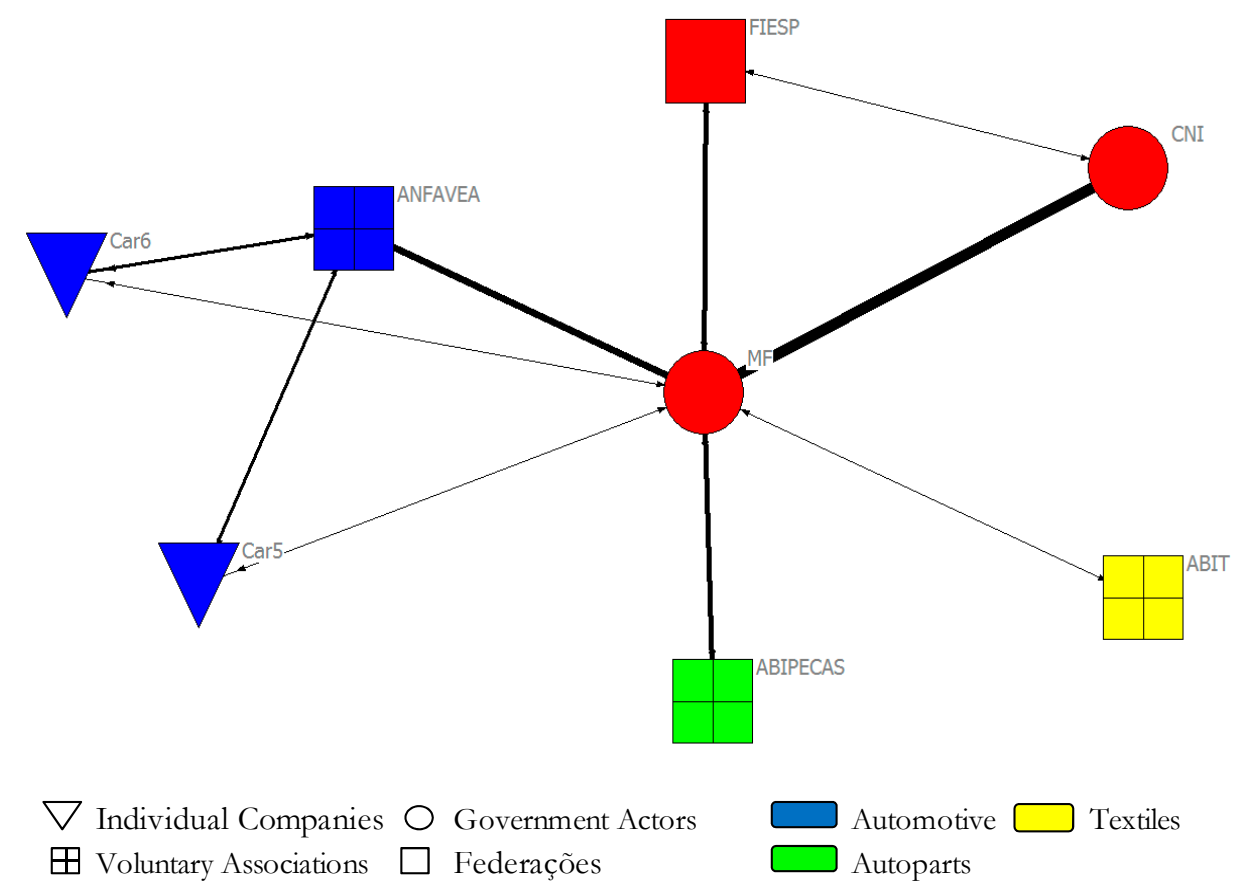

Figure 8. Direct relationships between the Economic Ministry (MF) and business associations (geodesic distance $=1$ ). 


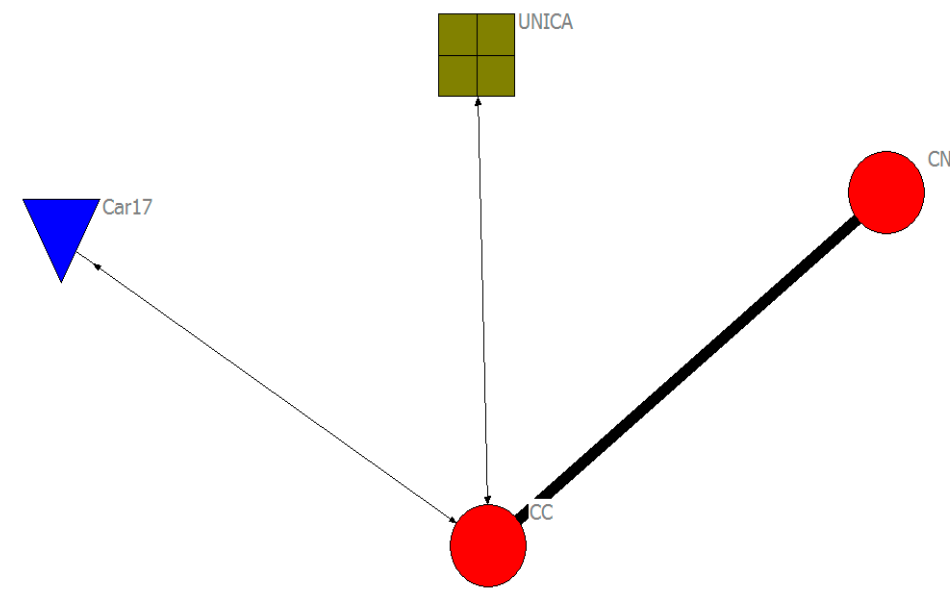

$\nabla$ Individual Companies $\bigcirc$ Government Actors $\square$ Automotive $\square$ Sugar \& Alcohol
$\boxplus$ Voluntary Associations

Figure 9. Direct relationships between the Civil House and business association.

The motor vehicle sector has a strong economic power that translates through its communication network as political power based on the intensity of their links and on the selection of the venue with the power to create policy. For instance, the automotive sector is at the top of Brazil's exports and plays a crucial role in Foreign Direct Investment, FDI. The government, through industrial incentives, has contributed to help these companies construct approximately 21 industrial plants within Brazil (Arbix 2006; Quadros and Consoni 2009). Regarding the number of employees, this sector ranks fifth, after the textile, footwear, auto parts, and sugar sectors. Moreover, this industry has historically been considered an important sector for the development of Brazil's economy and an engine for its development. For instance, during the government of Juceline Kubitscheck (1956-1961) and his five-year plan, the automobile industry played a crucial role in promoting Brazil's import-substitution development (Shapiro 1996). There have also been various accords signed between presidents and the motor vehicle sector (i.e., in 1991 under Fernando Collor de Mello, in 1993 under Itamar Franco, and in 1995 under Fernando Cardoso) (Fiuza 2002), reflecting the confluence of the interests of the government and the motor vehicle sectors.

The sugar/bioethanol sector is also a powerful and essential sector within Brazil. This country is the world's largest producer of sugar cane and second in bioethanol production after the United States. Brazil is responsible for 35 percent of the world's biofuel production and 30 percent of the world's sugar production. In the sugar/bioethanol sector, the government's original reticence to drop the CETs was the result of the high U.S. tariffs. The government was concerned that a unilateral reduction would not be effective in pressuring the United States to reduce their tariffs. Ethanol has been a contentious subject between the United States and Brazil since the United States levied a tariff of US $\$ 0.54$ per gallon on most ethanol imports. Because of Brazil's strong production and competitiveness in bioethanol, the sector initially lobbied the government to lower the CET to $0 \%$. The Brazilian ethanol tariff was supposed to remain in place until the end of 2011, but was extended until 31 December 2015. In 2017, the tariff increased again to 20 percent, beyond a 158.5 million gallon quota due to a 320 percent increase of imports from the United States, a decision supported by the sector and government (Tisheva 2017).

The development of the bioethanol industry has been a state industrial policy. Until 1999, Brazil's sugarcane sector was tightly regulated and subsidized by the state. In 1974, in response to the oil crisis, the military regime created the National Alcohol Program, called ProAlcool, with a goal of developing an alcohol program to diminish Brazil's dependency on foreign oil. The Sugar and Alcohol Institute (IAA) was also created to control the production and trading of all types of alcohol within the country 
(Moraes and Rodrigues 2006). The importance of this sector for the government is reflected in the privileged positions that these sectors have in the trade policy network. This sector is well-connected to the MDIC, MF, and CC (Figures 6-9 and Tables A1-A4). UNICA, a voluntary association, represents the sugar and bioethanol individual companies and its mandatory associations (i.e., the SIFAESP and SINDIAÇUCAR). UNICA has the second highest degree centrality within the network (68) (Table A1). The minister also met with two of its companies: Group Cosan (Sug 9) and Group Copersucar (Sug 8). The SIFAE-SP, the sindicato that represents the alcohol industry within the state of São Paulo, is highly connected to other actors, and SINDIAÇUCAR, from the state of Bahia, is connected to a few nodes. The reason for the SIFAESP's prominent level of connectivity is that many companies associated with UNICA are in São Paulo. UNICA and SINDIAÇUCAR share all their resources, such as websites, staff, buildings, and information, although this regional organization has its own president and board.

The footwear sector also communicates through strong pluralist policy networks with some corporatist characteristics; however, compared with the motor vehicle and sugar sectors, this sector accesses the government mostly through its voluntary and compulsory organizations and has few individual company connections (Figures 6-9). The footwear sector is outside of Mercosur CET and is well-protected with a CET of 35 percent. This industry occupies a central structural position within the network with a high centrality (50-degree centrality; Table A1) and is well-connected to the MDIC, but not to the other three ministries. This sector met with the MDIC minister through ABICALÇADO (its voluntary association) (50-degree centrality); individual companies, namely Calçados Azaléia (foot12) and São Paulo Alpargatas (foot87); and a mandated sindicato from Goias. This sector also has 37 syndicates connected to better-connected actors (eigenvector value ranges from 0.029 to 0.05 ). Of all these syndicates, SICF, from the city Franca within the state of São Paulo, has the highest degree of centrality (5) (Table A2). The footwear sector is a key industry in Brazil and the third largest exporter of footwear in the world, after China and India. The increment in the CET has positively affected this sector, according to Milton Cardoso, former president of ABICALÇADO and former chief executive officer (CEO) of the biggest footwear company, Grupo Vulcano/Azaléia. The production of footwear increased by 7.7 percent and the sector regained 44,000 jobs lost in 2008 before the CET was increased (Comunello 2011). This sector has also lobbied other members of Mercosur, to obtain approval for their tariff, and met with bureaucrats from Argentina, Paraguay, and Uruguay (Nakagawa-Folhapress 2007).

The impact of Chinese competition in the footwear industry has been intense (Magagna 1988). The footwear sector and other sectors, such as the textile sector and federal organization, called for government safeguards against Chinese exports because the products are cheaper and the competition unlawful. The footwear sector's concerns are echoed by the government, which considers China a contributor to the deindustrialization or primarization of the Brazilian economy (Jenkins and Barbosa 2012). Since 2010, the government of Brazil has created programs to support this sector's exports. Through industrial policy and its variety of targeted programs (e.g., Industrial, Technological, and Trade Policy (PITCE) and later, the Productive Development Policy (PDP)). Under the PDP, the government has supported select sectors, such as automotive, textiles and clothing, agroindustry, and biodiesel, in our sample with the goal of encouraging competitiveness in sectors that have potential but are experiencing problems. Other programs targeted leading sectors, such as bioethanol and meat processing, with the objective of expanding and consolidating their leadership (Santarcángelo et al. 2018). Until the mid-1960s, the footwear industry produced shoes mainly for the domestic market. In the late 1960s and beginning of the 1970s, this industry began exporting mainly women's footwear. During the 1970s and 1980s, the industry invested in the mechanization and modernization of the sector, and these innovations increased their level of exports five-fold, especially to the U.S. market (Alarcon and McKinley 1992). Under this political and economic environment, ABICALÇADOS, Brazil's footwear business association, was created in 1983, in order to coordinate the interests of their members. This association currently represents 111 companies and 35 local syndicates that encompass approximately 8000 companies from different regions. 
The other two sectors with pluralist policy networks are poultry and wheat. Although different from the aforementioned three sectors, they have weaker links to policy decision-makers based on the intensity of the links and their direct connections with the governmental decisional actors to whom they have access. The centrality measures for both sectors actors are lower than the mean links for the whole network. The degree centrality for ABEF, the poultry's voluntary association, is nine; see also the wheat sector with five (Table A1). The poultry tariff has been decreasing; it was 13.33 percent in 1995 and 11.2 percent in 2010. Notably, the wheat CET was 10 percent in 2010. Far from the stronger protection received by the sectors as mentioned above, the poultry sector connects to the MDIC and the president, and the wheat sector can only access the MDIC (Figure 6). ABEF met with the MDIC three times, and its associated companies (Rio Branco Alimentos, better known as PIF PAF, and Sertanejo Alimentos) also met. The wheat sector through ABITRIGO, its voluntary association, met with the MDIC and one of its members, Bunge Alimentos (Wheat5). The indirect ties of both sectors to key policy decision-makers are also low (See Table A4). ABEF, an organization founded in 1976 that has nine members today, has expanded to accommodate 30 companies. This subsector leads Brazil's meat exports. ABITRIGO has represented the wheat industry since 1991 and currently has 44 individual associated companies. This sector has a long history with the Brazilian government that dates back to import-substitution policies, in which the state intervened in the commercialization and industrialization of this sector. In the 1930s, to protect their interests against the state, the wheat sectors began organizing themselves into regional syndicates not recognized by the government until 1944 . In 1949, the government prohibited the import of wheat flour, and by 1952, the government began controlling all wheat imports and controlling and regulating the production of, and even setting the price for, wheat subproducts. This system remained in place for 23 years, until November 1990, when the role of the state as the sole economic-regulating entity was eliminated.

In contrast with other sectors, the wheat and poultry sectors are examples of the complex relations and interests between Argentina and Brazil. The flour mill sector is a very controversial sector within Mercosur, and especially between the trade relations of Brazil and Argentina. After intense lobbying from the Brazilian sector, the government agreed to reduce their tariff from 11.5 percent to 10 percent, provisionally, alluding to reasons of scarcity. Every year, this sector presents different justifications for reducing the wheat CET. Wheat is the second largest commodity that Brazil imports from Argentina, after automobiles. Wheat is a sensitive product because it is integral to the Brazilian's basic alimentary habits, that is, bread for Brazilians is of critical cultural importance. An increment in the prices would, therefore, influence inflation, which the MF follows closely. The Lula government considered the wheat sector an essential instrument for the further promotion of regional integration. Thus, despite the Brazilian sector's pressures on the government, a high wheat tariff has been maintained. Wheat is a sector where the interest of the government in integration has been preserved, sometimes at the expense of the sector. Even with these restrictions, the sector has managed to change select policies to a limited degree and, at least temporarily, their benefit.

Regarding poultry, Argentina has tried to protect its markets from Brazilian companies. Both governments have tried repeatedly to organize meetings and propose mechanisms for the private sector to manage their differences, but this approach has been unsuccessful. More than traditional tariffs, the nontariff barriers are a significant concern within this subsector. For instance, although the footwear tariff within the Mercosur countries has been eliminated, nontariff barriers have been created. In the poultry sector, Brazil occupies the third position in world production.

\subsubsection{Corporatist Networks}

The implication for corporatist networks is that the power, influence, and access interest groups have been reduced because of the hierarchical organization of the intermediation structure between the interest groups and government (Magagna 1988). The finding of the CETs networks supports this assertion because this subsector has received moderate protection from the government compared with the pluralist intermediation system. Under this structure, peak organizations have the most 
power because of their monopolistic control. The network also supports the assertion of the power of peak associations compared with other actors.

The textile sector, although less well-connected than the footwear sector, has many more ties with better-connected nodes than the soy and meat sectors. In 1995, the average nominal tariff for the textile sector was set at 18 percent, but Lula's second government raised it to 26 percent. This industry has claimed that with this protection, they can, to some degree, handle non-competitive practices from China, such as dumping, reduced taxes, and lower interest rates. The textile industry met directly with all of the government actors, except the $\mathrm{CC}$, through its corporatist network structure; they had the same number of meetings as the auto parts sector. The textile sector, similar to the footwear sector, is labor intensive and because of Chinese competition, also fought to place most of their product lines on Brazil's CET exemption list. The textile industry, through its voluntary association ABIT, met with the ministry the same number of times as the auto parts sector and has a degree centrality of 15 .

The ABIT is the voluntary association that represents the textile sector. This sector connects directly to the MDIC though ABIT and its regional syndicate from Minas Gerais (Figure 6). The textile sector is also represented by several sindicatos from regions such as Minas Gerais, São Paulo, and Rio de Janeiro, with two-degree centrality (Table A2) that connects indirectly with high connected actors. Based on the records, individual textile companies did not meet directly with the minister, although some had contact through a regional sindicato from Minas Gerais. ABIT, compared with the other sectors, represents the whole chain of production: cotton, textiles, and garments. The connection between the cotton growers and cotton yarn producers is made through many intermediated actors. The textile producers are predominantly formed by small companies, whereas the garment industry has a few big companies, and the rest are small (Idec 2005).

Similar to the textile sector, the auto parts sector occupies a similar position within the network, has a strong corporatist structure, and is protected with CETs of 16 percent (Figure 5). Despite the auto parts sector forming part of the automobile regime, this sector often has conflicting interests with the motor vehicle sector. The auto parts industry is represented by the voluntary association ABIPEÇAS and compulsory sectoral association SINDIPEÇAS, which occupies a middle position of importance within the network (14-degree centrality; Table A1). The auto parts sector was lobbying the government to eliminate the 40 percent discount that the car assemblers have received for the past ten years, for the imported auto parts used in their car manufacturing. The auto parts companies claimed these discounts, in conjunction with low external tariffs of 8 percent and 9 percent, put the domestic auto parts companies at a disadvantage, as they were strongly affected by the dollar devaluation. Therefore, to protect this industry, the government eliminated this discount for vehicle parts not produced within the region and increased tariffs to 14 percent and 18 percent. Although this sector has had relative success in conveying the negative consequences that existing trade policies have had on their trade balance to the government, this sector denounced that automobile companies continue to prefer imported parts. This sector has direct ties with the MDIC and the MF, which, based on their degree and eigenvector centrality, are the most important decision-makers in matters of the CETs (Tables A1-A3 and Figures 5-8). Although this sector does not connect directly to the other government actors, it continues to have access to the $\mathrm{CC}$ and the president through other associations and actors (though indirect ties; Table A4). None of the companies associated with ABIPEÇAS met with the minister directly. Auto parts, with a degree centrality of 14, also doubles the number of ties that the average actor has in the network; however, when comparing the ties of their sindicatos and individual firms, there is a vast contrast with ABIT, which has a similar degree centrality. The auto parts sector is represented by only one syndicate with ties to other actors, and none of its companies have ties with other actors within this network.

The next sector is the soybean oil sector, which is protected by a CET of 9.35 percent (see Figure 5). This sector is represented by ABIOVE, a voluntary association with weak access to the government through its corporatist structure. Compared with the number of ties that the average network actor has, ABIOVE has considerably fewer ties (five-degree centrality), met with the MDIC 8.3 times, and 
did not meet with any other ministry. Brazil is the world's second largest producer and exporter of soybeans. This association, founded in 1981, has nine companies that are responsible for 72 percent of the country's production. During the 1980s, the Empresa Brasileira de Pesquisa Agropecuária (EMBRAPA) developed a species of soybean adapted to the tropics. This new soybean development revolutionized soybean production because this crop could now be planted in the Cerrado, where a considerable extension of land provided an economy of scale (Saab et al. 2009).

Finally, the swine meat sector communicates through a corporatist network; although, in contrast with the other sectors above, it does not connect directly to any of the decider ministries within the CAMEX ministries. The swine meat producers are represented by ABIPECS, with 25 associated companies. ABIPECS has one of the lowest degrees of centrality among all the other subsectors' voluntary associations (five-degree centrality; Table A1). This sector's CET is one of the lowest in our sample (10 percent).

\subsubsection{Clientelist Networks}

The bovine sector met with governmental actors mainly through clientelist ties to the MDIC and the president (see Figures 6-9). A 10.9\% CET protects this sector (See Figure 5). ABIEC, representing the bovine meat exporters, was created in 1979 when the sector began to export. In the last five years, this sector's production has been consolidating, and JBR and Marfrig control 30 percent of the beef slaughterhouses. These two companies have also expanded to international markets where, in 2009, JBC acquired Swift from the United States and became the world's largest meat producer. ABIEC's centrality degree is two. In 2017, there were accusations that Brazil's Federal Bank favored the JBC by providing favorable terms since 2007. In addition, these companies were charged with corruption, that is, accused of bribing inspectors to ignore food safety. The meat industry exports are approximately two-thirds of that of the automotive sector. The footwear sector exports one-third less than that of the meat sector. Although, this sector has expressed that their main concern is not the formal tariff, but the non-tariffs barriers.

\subsection{Discussion}

A country is not a tabula rasa, where political-economic models are developed and implemented in a vacuum. By contrast, vestiges of political and economic models that organized the relations between the business sectors and the government in vogue at a specific time can coexist at different degrees when new models are implemented, especially in developing nations. Business-government links reflect the connections and power of interest groups within a historical perspective. Connections do not emerge spontaneously but are the result of multiple interactions and efforts in which both sets of actors-government and economic actors-engaged over time and formed diverse patterns of influence-corporatist, pluralist, and clientelist policy networks, which can coexist at the meso-level. In the last decades, the boundaries of authority and power between social interests and the government have become increasingly blurred (Laumann et al. 1985). This phenomenon is evident when we observe the role that the business sectors play in policymaking, compared with other groups engaged in creating trade policy and more intense in trade policy under RTAs, where the technical matter of setting CETs requires close relations with economic actors.

Because of historical developments and institutional design, the distribution of power has been uneven within governments and diverse economic organizations. The complexity of policy-making and especially trade policy within Brazil shows the diffusion of authority throughout multiple venues, as has been observed. This diversification has profound implications for policy making because interest groups have diverse opportunities for lobbying agencies with various degree of power. Therefore, policy proposals are advanced by skillful interest groups aware of the government bureaucracies' powers. Although, comparing trade policy-making within the legislative branch and the executive branch, the latter is more concentrated. Within the legislative side, interest groups need to spread wider to gain agenda-setting power. This is an assertion that needs to be empirically tested, but the 
results seem to suggest that trade policy through the executive side would encourage the concentration of few groups that already have historical ties with the government.

For organized interest groups, the selection of lobbying venue is of utmost importance and contributes to determining the attainment of their groups' goals. In addition, each policy venue is under a specific institutional structure that guides the behavior of government and the way the private sector relates to these institutions. Interest groups aware of these divisions use this knowledge to gain access to or influence over their government and to affect policy outcomes. Interest groups can be directly connected to key governmental actors, such as the MDIC, MF, and president, and can gain access indirectly through other well-connected actors, such as well-connected voluntary or compulsory organizations (E.g., CNI, CAN, and FIESP). Such direct ties provide these sectors the opportunity to present their concerns and opinions directly to policymaking deciders and access to information. Therefore, these networks are channels where resources move in both directions: from the government to business and from business to government. Thus, directly connected actors are expected to have potentially more influence in affecting policy matters compared with indirect ties. Compared with direct ties, indirect ties between governments and industrial actors would not be the most efficient path for changing CETs because these ties agglutinate many sectors. However, indirect ties are useful when sectors do not have direct ties to affect policy.

The results of the social network analysis are highly indicative of the access and influence of the different sectors. The network reflects the number of meetings between the different sectors and the government. Yet, these are formal meetings; it does not, therefore, consider other channels that the associations and companies may use. It is plausible, and perhaps likely, to assume that their actual access to the government is much higher and that formal access levels are highly correlated with informal access levels and frequency. In other words, informal access likely follows the tendency of the data presented.

As the results suggest sectors that have more pluralist-clientelist policy networks (e.g., automotive, sugar/bioethanol, footwear, wheat, and poultry sectors) have been able to extract better protection from the government compared with corporatist policy networks. Out of these industries, those that are connected to crucial government trade policy deciders formed the strongest pluralist network and have the most access and the greatest possibility to influence the government in their favor such as the automotive, sugar/bioethanol, and footwear sectors. These three industries have found a responsive government that has protected these industries with high CETs (35 percent-automotive or footwear) or changing its tariff when needed (sugar/bioethanol). These industries, their protection, and their access reflect the historical convergence of government development policies and the choosing of specific industries and the industries' preferences.

Other pluralist policy structures do not have the same influence, though these industries are protected, but in a lesser manner (poultry and wheat-with a tariff around 9.5 percent). Strong, well connected corporativist policy structures such as textile, auto parts, and vegetable oil sectors have received a moderate rate of protection comparable to the weak pluralist policy network structures that do not directly connect with key governmental venues. The corporativist connection in the case of Brazil is embedded in a hierarchical pyramidal structure that primarily encourages more vertical relations among associations, to the detriment of horizontal and national representation (Pinto 2001). The structure of this organization creates a highly fragmented business-government system. In addition, clientelist policy networks connected to trade policy 'decider' would be the sectors that are most connected. In our sample, the swine sector uses these strategies; however, we do not have precise data to provide a strong argument because this sector is highly competitive and is more concerned in advocating for non-tariff barriers.

\section{Conclusions}

Trade policymaking has been described as a 'policy market' in which the interconnection of the demand for policy coming from interest groups and the supply of policy provided by the state is 
essential to explain trade policymaking. One of the merits of this paper is that it accounts for the co-influence of business and the government, which is significant, because different formations contribute to different policy outcomes and some formations are more successful than others (e.g., strong pluralist/clientelist policy networks over weak pluralism and strong corporatism). The characterization of these connections as policy networks with identifiable structures that can be measured using formal social network analysis helps to empirically identify the con-influence and the different positions that actors occupy within the network. In addition, this paper also extends the protectionist trade literature that empirically analyzes the interconnection between the legislative branch and the interest groups to the interconnections of these private groups in the executive branch. The study of the executive branch is essential not only because many countries trade policymaking is done through the executive branch, with little or no oversight from the legislative branch, but also because the executive branch has been gaining power in matters of trade even in countries where the legislature has historically been the main venue, such as the United States. It is important to clarify that the existence of a social network alone cannot explain CETs. Although, close-tied networks enhance the opportunities and the likelihood of the sectors in influencing government policy decision-making. In addition, understanding that these networks are embedded in broader government societal structures is vital. This paper complements the trade literature on the legislative side by pointing to the importance of policy networks as an intervenient variable that could bridge the gap between interest groups' economic power and their translation into political power through policy networks.

Future research should advance the systematic analysis of interest groups resources and delve into the connections between these and specific types of interest groups-government policy networks. Another interesting topic is the comparison of trade policy-making through the executive and legislative side and their repercussion in CETs.

Funding: This research received no external funding.

Conflicts of Interest: The author declares no conflict of interest.

\section{Appendix A}

Table A1. Voluntary associations' degree centrality.

\begin{tabular}{ccc}
\hline \multicolumn{3}{c}{ Voluntary Associations } \\
\hline Name & Degree & Sector \\
\hline ANFAVEA & 69 & Automotive \\
UNICA & 68 & Sugar \\
ABICALCADO & 50 & Footwear \\
ABIT & 15 & Textile \\
ABIPECAS & 14 & Autoparts \\
ABEF & 9 & Poultry Meat \\
ABITRIGO & 5 & Wheat Mill \\
ABIPECS & 5 & Swine Meat \\
ABIOVE & 5 & Soy \\
ABIEC & 2 & Bovine Meat \\
\hline
\end{tabular}


Table A2. Compulsory associations' degree centralities by economic subsector.

\begin{tabular}{|c|c|c|c|c|c|c|c|c|}
\hline \multicolumn{8}{|c|}{ Mandatory Associations } & \\
\hline Name & Degree & Name & Degree & Name & Degree & Name & Degree & \\
\hline SIFAESP-SP & 58 & FIEPB & 2 & FIERN & 2 & SINDINOVA-MG & 2 & \\
\hline CNI & 45 & FIEPE & 2 & SINDCALCADOS-PB & 2 & SINDITEXTIL-SP & 2 & \\
\hline FIERS & 16 & SICERGS-RS & 2 & SINDCALF-RS & 2 & SIVENSUL-RS & 2 & \\
\hline FIEMG & 13 & SICESP-SP & 2 & SINDCALT-RS & 2 & FIEG & 2 & Sectors: \\
\hline SICF-SP & 5 & SICEVEV-RS & 2 & SINDIACUCAR-BA & 2 & SINDIMALHAS-MG & 2 & Automotive \\
\hline SINDOLEO-SP & 4 & FIEA & 2 & SINDICAL-MS & 2 & SICS-RS & 2 & Autoparts \\
\hline SINDICALCADOS-ES & 3 & SICNH-RS & 2 & FIRJAN & 2 & FINDES & 1 & Footwear \\
\hline FIEAM & 3 & SICJ-SP & 2 & SINDICALCADOS-MG & 2 & FIEPA & 1 & Sugar \\
\hline FIEB & 3 & FIESC & 2 & SINDICALDI-RS & 2 & FIEAC & 1 & Poultry Meat \\
\hline SINBI-SP & 3 & SINCALCADO-MA & 2 & SINDICALJN-CE & 2 & FIBRA & 1 & Swine Meat \\
\hline FIEC & 3 & SINCALCB-RS & 2 & SINDICAP-RS & 2 & FIAP & 1 & Bovine Meat \\
\hline SINDICALCE-GO & 3 & SINCALCRJ-RJ & 2 & SINDICAU-MG & 2 & FIES & 1 & Wheat Mill \\
\hline SINDCALCADOS-BA & 3 & SINCALIG-RS & 2 & SINCALCADO-AL & 2 & FIEPI & 1 & Soy \\
\hline FIEMS & 3 & SINCALUBL-MG & 2 & SINDIMAQ & 2 & FIER & 1 & Federations \\
\hline FIEMA & 2 & SINCASJB-SC & 2 & SINFAVEA & 2 & FIEMT & 1 & Peak Association \\
\hline
\end{tabular}

Note: The color represents different sectors. See color key table. 
Table A3. Individual companies' degree centrality by economic subsector

\begin{tabular}{|c|c|c|c|c|c|c|c|c|c|c|}
\hline \multirow[b]{2}{*}{ Name } & \multirow[b]{2}{*}{ Degree } & \multicolumn{4}{|c|}{ Individual Companies } & \multirow[b]{2}{*}{ Name } & \multirow[b]{2}{*}{ Degree } & \multirow[b]{2}{*}{ Name } & \multirow[b]{2}{*}{ Degree } & \\
\hline & & Name & Degree & Name & Degree & & & & & \\
\hline Car24 & 23 & Oil6 & 3 & Foot80 & 2 & Sug24 & 2 & Sug49 & 2 & \\
\hline Car6 & 16 & Sug9 & 3 & Foot87 & 2 & Sug47 & 2 & Sug45 & 2 & Sectors: \\
\hline Car5 & 12 & Meat2 & 3 & Foot12 & 2 & Sug 48 & 2 & Sug46 & 2 & Automotive \\
\hline Car21 & 7 & Poul22 & 3 & Foot19 & 2 & Sug29 & 2 & Sug51 & 2 & Autoparts \\
\hline Car16 & 6 & Car4 & 3 & Foot55 & 2 & Sug3 & 2 & Sug52 & 2 & Textile \\
\hline Car26 & 6 & Sug16 & 3 & Sug28 & 2 & Sug50 & 2 & Sug5 & 2 & Footwear \\
\hline Car8 & 6 & Poul9 & 3 & Sug1 & 2 & Sug31 & 2 & Sug55 & 2 & Sugar \\
\hline Car20 & 6 & Poul23 & 2 & Sug10 & 2 & Sug32 & 2 & Sug20 & 2 & Poultry Meat \\
\hline Car22 & 6 & Poul4 & 2 & Sug11 & 2 & Sug38 & 2 & Sug19 & 2 & Swine Meat \\
\hline Car7 & 5 & Poul14 & 2 & Sug53 & 2 & Sug44 & 2 & Whea5 & 2 & Bovine Meat \\
\hline Car1 & 5 & Sug30 & 2 & Sug54 & 2 & Sug35 & 2 & Whea1c & 2 & Wheat Mill \\
\hline Car19 & 5 & Sug13 & 2 & Sug14 & 2 & Sug36 & 2 & Tex35 & 2 & Soy \\
\hline Poul20 & 5 & Sug33 & 2 & Sug56 & 2 & Sug37 & 2 & & & \\
\hline Car9 & 5 & Sug23 & 2 & Sug17 & 2 & Sug42 & 2 & & & \\
\hline Sug8 & 4 & Sug12 & 2 & Sug18 & 2 & Sug39 & 2 & & & \\
\hline Car23 & 4 & Oil8 & 2 & Sug2 & 2 & Sug4 & 2 & & & \\
\hline Car3 & 4 & Sug22 & 2 & Sug21 & 2 & Sug40 & 2 & & & \\
\hline Car12 & 3 & Sug34 & 2 & Sug43 & 2 & Sug41 & 2 & & & \\
\hline Oil5 & 3 & Sug15 & 2 & Sug26 & 2 & Sug6 & 2 & & & \\
\hline Car17 & 3 & Sug27 & 2 & Sug25 & 2 & Sug7 & 2 & & & \\
\hline
\end{tabular}


Table A4. Eigenvector centrality measures by subsector.

\begin{tabular}{|c|c|c|c|c|c|c|c|c|c|c|}
\hline Eigenv. & Actor & Eigenv. & Actor & Eigenv. & Actor & Eigenv. & Actor & Eigenv. & Actor & \\
\hline 0.704 & UNICA & & Sug30 & \multirow{5}{*}{0.051} & Car19 & \multirow{3}{*}{0.017} & SICI-SP & \multirow{10}{*}{0.09} & SICI-RS & \multirow[b]{8}{*}{ Sectors: } \\
\hline 0.658 & SIFAESP-SP & & Sug31 & & Car20 & & SINBI-SP & & SINCALCB-RS & \\
\hline 0.158 & Sug8 & & Sug32 & & Car21 & & Whea10 & & SINCALIG-RS & \\
\hline 0.141 & Sug9 & & Sug33 & & Car23 & \multirow{3}{*}{0.016} & ABIMAQ & & SINDCALF-RS & \\
\hline 0.135 & FIESP & & Sug34 & & Car24 & & SINDIACUCAR-BA & & SINDCALT-RS & \\
\hline 0.133 & Sug16 & & Sug35 & 0.048 & ABIT & & SINDITEXTIL-SP & & SINDCALDI-RS & \\
\hline 0.126 & ANFAVEA & & Sug36 & 0.047 & ABIPECAS & \multirow{2}{*}{0.014} & Car12 & & SINDICAP-RS & \\
\hline \multirow{27}{*}{0.119} & Sug1 & & Sug37 & 0.043 & Poul20 & & Car4 & & SINDIMET-RS & \\
\hline & Sug2 & & Sug38 & 0.042 & FIERS & 0.013 & SINDOLEO-SP & & SINDIVESTCAL-RS & Automotive \\
\hline & Sug3 & & Sug39 & \multirow{3}{*}{0.04} & Car25 & \multirow[b]{2}{*}{0.011} & FIEB & & SINDIVENSUL-RS & Autoparts \\
\hline & Sug4 & & Sug40 & & Car26 & & FIEG & \multirow{5}{*}{0.07} & ABIEC & Footwear \\
\hline & Sug5 & & Sug41 & & Meat2 & \multirow{7}{*}{0.01} & FIEC & & Foot19 & Textile \\
\hline & Sug6 & & Sug42 & 0.036 & Car1 & & SINAJ-MG & & Foot55 & Poultry \\
\hline & Sug7 & \multirow{14}{*}{0.119} & Sug43 & & Car8 & & SINDIMAQ & & Foot80 & Sugar/bioethanol \\
\hline & Sug10 & & Sug44 & 0.034 & Car22 & & SINCALUBL-MG & & SINDICAL-MS & Swine \\
\hline & Sug11 & & Sug45 & \multirow{3}{*}{0.032} & ABAG & & SINDICALCADOS-N & \multirow{11}{*}{0.06} & Oil5 & Bovine \\
\hline & Sug12 & & Sug46 & & FIEAM & & SINDICALU-MJ & & Oil6 & Soy \\
\hline & Sug13 & & Sug47 & & FIERN & & SINDINOVA-MG & & Poul9 & Wheat \\
\hline & Sug14 & & Sug48 & 0.03 & ABEF & \multirow{16}{*}{0.09} & FIAP & & SINDICALCADO-AL & Peak Association \\
\hline & Sug15 & & Sug49 & & Foot12 & & FIBRA & & SINCALCADO-MA & Federations \\
\hline & Sug17 & & Sug50 & 0.028 & Foot87 & & FIEA & & SINCALCRI-RJ & Others \\
\hline & Sug18 & & Sug51 & 0.027 & SINDIMALHAS-MG & & FIEAC & & SINCASJB-SC & \\
\hline & Sug19 & & Sug52 & \multirow{3}{*}{0.026} & ABIA & & FIEMA & & SINDICANCADOS-BA & \\
\hline & Sug20 & & Sug53 & & ABITRIGO & & FIEMT & & SINDICAL-CE & \\
\hline & Sug21 & & Sug54 & & Poul22 & & FIEPA & & SINDICAL-PE & \\
\hline & Sug22 & & Sug55 & 0.025 & Whea5 & & FIEPB & & SINDICAIJN-CE & \\
\hline & Sug23 & & Sug56 & \multirow{3}{*}{0.024} & ABIOVE & & FIEPI & 0.05 & SINDICALCADOS-ES & \\
\hline & Sug24 & 0.071 & Car6 & & FIEMS & & FIER & \multirow{7}{*}{0.03} & ABIPECS & \\
\hline & Sug25 & 0.058 & Car5 & & FIEPAR & & FIES & & Oil8 & \\
\hline & Sug26 & 0.053 & FIEMG & \multirow{2}{*}{0.019} & SICF-SP & & FIESC & & Poul14 & \\
\hline & Sug27 & \multirow{4}{*}{0.051} & Car3 & & Tex35 & & FIET & & Poul23 & \\
\hline & Sug28 & & Car7 & \multirow[b]{2}{*}{0.018} & Car17 & & FIRJAN & & Poul4 & \\
\hline & Sug29 & & Car9 & & SINDIPECAS & & SICERGS-RS & & & \\
\hline & & & Car16 & 0.017 & SICESP-SP & & SICEEVEV-RS & & & \\
\hline
\end{tabular}


Table A5. List of people interviewed.

\begin{tabular}{|c|c|c|}
\hline \multicolumn{3}{|c|}{ GOVERNMENT ACTORS } \\
\hline Name & Title & Ministry/Organization \\
\hline $\begin{array}{l}\text { Reinaldo José de Almeida } \\
\text { Salgado }\end{array}$ & $\begin{array}{l}\text { Head of DMC-Divisão do Mercado Comum do Sul } \\
\text { (South American Common Market Division) }\end{array}$ & $\begin{array}{l}\text { Foreign Affairs Ministry } \\
\text { (MRE)/DMC }\end{array}$ \\
\hline João Mendes Pereira & $\begin{array}{l}\text { Head of DIR-Divisão de Integração Regional } \\
\text { (Regional integration Division) }\end{array}$ & MRE/DIR \\
\hline $\begin{array}{l}\text { Aloisio Tupinambá Gomes } \\
\text { Neto }\end{array}$ & $\begin{array}{l}\text { Especial Advisor for the head of CAMEX (Assessor } \\
\text { Especial do Secretário-Executivo da CAMEX) }\end{array}$ & $\begin{array}{l}\text { Ministry of Development, } \\
\text { Industry and Trade } \\
\text { (MDIC)/CAMEX }\end{array}$ \\
\hline Weber Barral & $\begin{array}{c}\text { Secretary of Foreign Affairs-Secretário do Comércio } \\
\text { Exterior }\end{array}$ & MDIC/SECEX \\
\hline $\begin{array}{l}\text { Gilberto Aluísio Monteiro } \\
\text { Larcher }\end{array}$ & $\begin{array}{l}\text { Head of Mercosur Division-Chefe de Divisão do } \\
\text { Mercosur }\end{array}$ & MDIC/SECEX/DEINT \\
\hline Eliane de Souza Fontes & $\begin{array}{c}\text { Director for the Department of International } \\
\text { integration (Coordenador-Geral de Integração } \\
\text { Regional-DEINT) }\end{array}$ & MDIC/SECEX/DEINT \\
\hline Rafaela Viera & Departamento de defense Commercial (DECOM) & MDIC/SESEX/DECOM \\
\hline Zick Moisés Jr. & $\begin{array}{l}\text { Coordinator for the Chemical Industry and Others } \\
\text { (Coordenador-Geral das Indústrias Químicas e de } \\
\text { Transformados Plásticos) }\end{array}$ & $\begin{array}{l}\text { MDIC/Secretaria de } \\
\text { Desenvolvimento da } \\
\text { Produção-SDP }\end{array}$ \\
\hline Pedro Florencio & $\begin{array}{l}\text { Departamento Coordenação Geral de Políticas } \\
\text { Comerciais within the Secretaria de Assuntos } \\
\text { Internacionais (SAIN) }\end{array}$ & MF/SAIN \\
\hline Fernando Alcaraz & $\begin{array}{l}\text { Coordenação Geral de Políticas Comerciais within } \\
\text { the Secretaria de Assuntos Internacionais (SAIN) }\end{array}$ & $\begin{array}{l}\text { Ministerio da Fazenda } \\
\text { (MF)/SAIN }\end{array}$ \\
\hline Antonio Jose Alves Junior & $\begin{array}{l}\text { Special Advisor for the Minister of the Ministry of } \\
\text { State (Assesor-chefe da Assesoria Especial da Casa } \\
\text { Civil) }\end{array}$ & Civil house (CS) \\
\hline Paulo Nicola Venturelli & $\begin{array}{c}\text { General Coordinator of Regional } \\
\text { Integration-(Coordenação-Geral De Integração } \\
\text { Regional-CGIR/Dac (Departamento De Assuntos } \\
\text { Comerciais)) }\end{array}$ & $\begin{array}{l}\text { Ministry of Agriculture } \\
\text { (MAPA)/SRI (Secretaria de } \\
\text { Relações Internacionais do } \\
\text { Aronegócio) }\end{array}$ \\
\hline Patrycia Werneck & $\begin{array}{c}\text { Coordinator of the Department of Commercial } \\
\text { Matters (Coordenadora do Departamentos de } \\
\text { Asuntos Comerciales) }\end{array}$ & MAPA/SRI \\
\hline Lino Colser & $\begin{array}{c}\text { International Relations Secretary (Secretário } \\
\text { substituto da Secretaria de Relações Internacionais) }\end{array}$ & MAPA/SRI \\
\hline Paulo Marchesiini Neto & $\begin{array}{l}\text { Assistant to the Secretary for of International Affairs } \\
\text { (Asessor da Secretaria de asusntos } \\
\text { internacionales-SEAIN) }\end{array}$ & MPOG/SEAIN \\
\hline $\begin{array}{l}\text { Francisco Carneiro de } \\
\text { Phhillipo }\end{array}$ & $\begin{array}{l}\text { Coordinator for International Negotiations } \\
\text { (Coordenator de naegociaciones interantionals) }\end{array}$ & MPOG/SEAIN \\
\hline $\begin{array}{l}\text { Patricia Matos Magalhães } \\
\text { Albuquerque }\end{array}$ & $\begin{array}{l}\text { Assistant to the Secretary of International Affairs } \\
\text { (SEAIN) }\end{array}$ & MPOG/SEAIN \\
\hline Paulo Peixoto & $\begin{array}{l}\text { National Coordinator of the Cooperation Committee } \\
\text { of Technical Cooperation within Mercosur (CCT) }\end{array}$ & $\mathrm{MRE} / \mathrm{CCT}$ \\
\hline Dr. Rosinha & Deputy from the PT (Workers Party) & Brazilian Congress \\
\hline José Everaldo Ramalho & Brazilian Representative to the Mercosur Parliament & $\begin{array}{l}\text { Comision de Mercosur da } \\
\text { Camara }\end{array}$ \\
\hline
\end{tabular}


Table A5. Cont.

\begin{tabular}{|c|c|c|}
\hline \multicolumn{3}{|c|}{ BUSINESS ACTORS } \\
\hline Name & Association or Company & Sector \\
\hline Domingo Mosca & ABIT & Textile \\
\hline Ana Paula Ciufa & ABIT & Textile \\
\hline Luis Martins & ABITRIGO/Anaconda & Wheat Mills \\
\hline Eduardo de Paula Ribeiro & FIESP & $\begin{array}{c}\text { Mandatory Business } \\
\text { Federation from São Paulo }\end{array}$ \\
\hline Alberto Pfeifer & Business Council of Latin America (CEAL) & $\begin{array}{l}\text { Voluntary encompassing } \\
\text { association }\end{array}$ \\
\hline Antonio Sergio Martins & FIAT/ANFAVEA & Automotive \\
\hline Rogelio Golfarb & Ford & Automotive \\
\hline Marcos Saltini & Volkswagen-Trucks & Automotive \\
\hline Antonio Megale & Volkswagen-Cars & Automotive \\
\hline Rogério Rezende & Scania Latino América & Automotive \\
\hline Pedro Gabriel Betancourt & General Motors & Automotive \\
\hline Marcos Viera de Souza & General Motors & Automotive \\
\hline Vinisious Pratini de Morais & JBS/ABIEC & Meat \\
\hline Aguinaldo Diniz Filho & Cedro Cachoeira & Textiles \\
\hline Eduardo de Palma Ribeiro & Suap & Textiles \\
\hline João Karsen & Karsen & Textiles \\
\hline Ulrich Khun & Hering & Textiles \\
\hline Luis Fernando Brandt & Teka & Textiles \\
\hline Rolf Buddemeyer & Buddemeyer & Textiles \\
\hline Alvaro & M.Dias & Wheat \\
\hline Antenor Barros Leal & Predileto & Wheat Mills \\
\hline Cristian Saigh & Molinho Sta. Clara & Wheat Mills \\
\hline Amarílio Proença de Macêdo & J. Macêdo & Wheat Mills \\
\hline Benedito Foseca Moreira & $\begin{array}{c}\text { Foreign Trade Association (Associação de Comercio } \\
\text { Exterior AEB) }\end{array}$ & Voluntary Peak Association \\
\hline \multicolumn{3}{|c|}{ OTHERS } \\
\hline Márcia Lopes & $\begin{array}{l}\text { Valor Econômico (area-textile, meat, and } \\
\text { automotive sector) }\end{array}$ & Journalist \\
\hline Claudia Facchini & $\begin{array}{l}\text { Valor Econômico (area-sugar and alcohol, and } \\
\text { appliances) }\end{array}$ & Journalist \\
\hline Sergio Leo & Valor Econômico (International area) & Journalist \\
\hline Maria Jose de Caravalho & Textilia & Textile Specialized Magazine \\
\hline João Abdalla Neto & World Fair & Consulting Firm \\
\hline Ricardo Camargo Mendes & Prospectiva & Consulting Firm \\
\hline Sergio Amaral & $\begin{array}{l}\text { Former Brazilian Embasador and member of } \\
\text { Felsberg e Associados }\end{array}$ & Consulting Firm \\
\hline
\end{tabular}

\section{References}

Agranoff, Robert, and Michael McGuire. 1998. Multinetwork Management: Collaboration and the Hollow State in

Local Economic Policy. Journal of Public Administration Research and Theory 8: 67-91. [CrossRef]

Agranoff, Robert. 2007. Managing Within Networks: Adding Value to Public Organizations. Washington: Georgetown

University Press. 
Alarcon, Diana, and Terry McKinley. 1992. Beyond Import Substitution: The restructuring projects of Brazil and Mexico. Latin American Perspectives 19: 72-87. [CrossRef]

Alt, James E., and Michael Gilliga. 1994. The Political Economy of Trading States: Factor Specificity, Collective Action Problems and Domestic Political Institutions. The Journal of Political Philosophy 2: 165-92. [CrossRef]

Arbix, Glauco. 2006. Guerra fiscal, espaço público e indústria automobilística no Brasil. In A Indústria Automobilística nas Américas-A Reconfiguração Estratégica e Social dos Atores. Edited by Adalberto Cardoso and Alex Covarrubias. Minas Gerais: UFMG.

Bhagwati, Jagdish. 1982. Directly Unproductive Profit-Seeking (DUP) Activities. Journal of Political Economy 90: 988-1002. [CrossRef]

Borzel, Tanja A. 1998. Organizing Babylon- On the Different Conceptions of Policy Networks. Public Administration 76: 253-73. [CrossRef]

Tisheva, Plamena. 2017. Brazil approves 20\% tariff on ethanol imports beyong quota. Renewables Now, August 24.

Broscheid, Andreas, and David Coen. 2003. Insider and Outsider Lobbying in the European Commission. European Union Politics 4: 165-89. [CrossRef]

Cason, Jeffrey W., and Timothy J. Power. 2009. Presidentialization, pluralization, and the rollback of Itamaraty: Explaining change in Brazilian foreign policy making in the Cardoso-Lula era. International Political Science Review/Revue Internationale de Science Politique 30: 117-40. [CrossRef]

Chase, Kerry A. 2003. Economic Interests and Regional Trading Arrangements: The Case of NAFTA. International Organization, Winter 57: 137-74. [CrossRef]

Cohen, Benjamin J. 1990. The Political Economy of International Trade. International Organization 44: $261-81$. [CrossRef]

Comunello, Patricia. 2011. Abicalçados alerta que setor está às portas de nova crise. Jornal do Comércio, May 17.

Saab, Maria Stella, Matheus Alberto Consoli, and Vinícius Gustavo Trombin. 2009. Mapping and quantification of the meat chain in Brazil. Paper presented at VII International PENSA Conference, Sao Paulo, Brazil, November 26-28.

Destler, Irving M. 1986. American Trade Politics: System Under Stress. Washington: Institute for Inter- national Economics.

Destler, Irving M. 2015. Presidents, Bureaucrats and Foreign Policy: The Politics of Organizational Reform. Princeton: Princeton Legacy Library, Princeton University Press.

Dür, Andreas. 2008. Bargaining Power and Trade Liberalization: European External Trade Policies in the 1960s. European Journal of International Relations 14: 645-69. [CrossRef]

Eckhardt, Jappe. 2015. Business Lobbying and EU Trade Governance in a World of Global Value Chains. In Business Lobbying and Trade Governance: The Case of EU-China Relations. New York: Palgrave Macmillan, pp. 15-38.

Fiuza, Eduardo P.S. 2002. Automobile Demand and Supply in Brazil: Effects of Tax Rebates and Trade Liberalization on Markups in the 1990s. Rio de Janeiro: Instituto de Pesquisa Econômica Aplicada-IPEA.

Freeman, J. Leiper, and Judith Parris Stevens. 1987. A Theoretical and Conceptual Re-examination of Sub-system Politics. Public Policy and Administration 2: 9-25. [CrossRef]

Freeman, Linton C. 1979. Centrality in social networks: Conceptual clarification. Social Networks 1: $215-39$. [CrossRef]

Godek, Paul E. 1985. Industry Structure and Redistribution through Trade Restrictions. Journal of Law and Economics 28: 687-703. [CrossRef]

Greenwood, Justin. 2003. Interest Representation in the European Union. New York: Palgrave Macmillan.

Grossmann, Matt. 2012. Not-So-Special Interests: Interest Groups, Public Representation, and American Governance. Palo Alto: Stanford University Press.

Haas, Peter M. 1992. Epistemic Communities and International Policy Coordination. International Organization 46: 1-35. [CrossRef]

Heclo, Hugo. 1978. Issue Netroks and The Executive Establishment. In The New American Political System. Edited by Anthony King. Washington: American Enterprise Institute.

Idec. 2005. Cadeia de Valor do Algodão, Têxtil e Vestuário: Um Estudo Prospectivo. Available online: http: / / www.idec.org.br/arquivos/relatorio_cadeia_algodao.pdf (accessed on 15 January 2009).

Jenkins, Rhys, and Alexandre de Freitas Barbosa. 2012. Fear for Manufacturing? China and the Future of Industry in Brazil and Latin America. The China Quarterly 209: 59-81. [CrossRef] 
Jordan, Grant, and Klaus Schubert. 1992. A preliminary ordering of policy network labels. European Journal of Political Research 21: 7-27. [CrossRef]

Kay, Tamara. 2011. NAFTA and the Politics of Labor Transnationalism. Cambridge: Cambridge University Press.

Kay, Tamara. 2015. New challenges, new alliances: Union politicization in a post-NAFTA era. Labor History 56: 246-69. [CrossRef]

Keedi, Samir. 2007. Abc do Comércio Exterior: Abrindo as Primeiras Páginas. São Paulo: Aduaneiras.

Knoke, David, and Edward O. Laumann. 1982. The social organization of national policy domains: An exploration of some structural hypotheses. In Social Structure and Network Analysis. Edited by Peter V. Marsden and Nan Lin. Beverly Hills: Sage, pp. 255-70.

Krueger, Anne O. 1990. Government Failures in Development. The Journal of Economic Perspectives 4: 9-23. [CrossRef]

Kunzler, Jacob Paulo. 2002. Mercosul e o Comércio Exterior. São Paulo: Aduaneiras.

Laumann, Edward O., David Knoke, and Yong-Hak Kim. 1985. An organizational approach to state policy formation: A comparative study of energy and health domains. American Sociological Review 50: 1-19. [CrossRef]

Laumann, Edward O., and David Knoke. 1987. The Organizational State: A Perspective on National Energy and Health Domains. Madison: University of Wisconsin Press.

Laumann, Edward O., Peter V. Marsden, and David Prensky. 1992. The Boundary Specification Problem in Network Analysis. In Research Methods in Social Network Analysis. Edited by Linton C. Freeman, Douglas R. White and A. Kimball Romney. New Brunswick: Transaction Publishers.

Lindblom, Charles E. 1977. Politics and Markets: The World's Political Economic Systems. New York: Basic Books.

Magagna, Victor V. 1988. Representing Efficiency: Corporatism and Democratic Theory. The Review of Politics 50: 420-44. [CrossRef]

Magee, Stephen P., William A. Brock, and Leslie Young. 1989. Black Hole Tariffs and Endogenous Policy Theory. Cambridge: Cambridge University Press.

Mahoney, Christine. 2008. Brussels Versus the Beltway: Advocacy in the United States and the European Union. Washington: Georgetown University Press.

Marvel, Howard P., and Edward J. Ray. 1983. The Kennedy Round: Evidence on the Regulation of International Trade in the United States. The American Economic Review 73: 190-97.

Moore, Michael O. 1990. New Developments in the Political Economy of Protectionism. In Imperfect Competition and Political Economy. Edited by Colin A. Carter, Alex F. McCalla and Jerry A. Sharples. Boulder: Westview Press.

Moore, Michael O. 1992. Bureaucratic Trade-Policy Decisions as a Repeated Game. Journal of Institutional and Theoretical Economics (JITE) 148: 607-27.

Moraes, Márcia Azanha Ferraz Dias de, and Luciano Rodrigues. 2006. Brazil's Alcohol National Program. São Paulo: University of São Paulo (USP-ESALQ).

Nakagawa-Folhapress, Fernando. 2007. Mercosul aprova elevação da tarifa de calçados. Folhadaregiao.com, July 19.

Nelson, Douglas. 1988. Endogenous Tariff Theory: A Critical Survey Endogenous Tariff Theory: A Critical Survey. American Journal of Political Science 32: 796-837. [CrossRef]

O'Toole, Laurence J. 1988. Strategies for intergovernmental management: Implementing programs in interorganizational networks. International Journal of Public Administration 11: 417-41. [CrossRef]

Olarreaga, Marcelo, and Isidro Soloaga. 1998. Endogenous Tariff Formation: The Case of Mercosur. The World Bank Economic Review 12: 297-320. [CrossRef]

Pincus, Jonathan J. 1975. Pressure Groups and the Pattern of Tariffs. Journal of Political Economy 83: 757-78. [CrossRef]

Pinto, André Lipp. 2001. Soberania, Omc e Mercosul. São Paulo: Aduaneiras.

Quadros, Ruy, and Flavia Consoni. 2009. Innovation capabilities in the Brazilian automobile industry: A study of vehicle assemblers' technological strategies and policy recommendations. International Journal of Technological Learning, Innovation and Development 2: 53-75. [CrossRef]

Richardson, Jeremy John, and Grant Jordan. 1979. Governing Under Pressure: The Policy Process in a Post-Parliamentary Democracy. Oxford: Blackwell Publishers.

Rosenbaum, Michael. 1999. Domestic Bureaucracies and the International Trade Regime: The Law and Economics of Administrative Law and Administratively Imposed Trade Barriers. In Harvard Law School John M. Olin Center for Law Economics an Busniess. Discussion paper series; Paper 250. Boston: Harvard Law School. 
Santarcángelo, Juan E., Daniel Schteingart, and Fernando Porta. 2018. Industrial Policy in Argentina, Brazil, Chile and Mexico: A Comparative Approach. Revue Interventions Economiques 59: 1-42.

Saunders, Ronald S. 1980. The Political Economy of Effective Tariff Protection in Canada's Manufacturing Sector. The Canadian Journal of Economics/Revue canadienne d'Economique 13: 340-48. [CrossRef]

Schneider, Volker. 1992. The Structure of Policy Networks. European Journal of Political Research 21: 109-29. [CrossRef]

Shaffer, Gregory C. 2003. Defending Interests: Public-Private Partnerships in WTO Litigation. Washington: Brookings Institution Press.

Shapiro, Helen. 1996. The mechanics of Brazil's auto industry. NACLA's Report on the Americas 29: 28-33. [CrossRef]

Trefler, Daniel. 1993. Trade Liberalization and the Theory of Endogenous Protection: An Econometric Study of U.S. Import Policy. The Journal of Political Economy 101: 138-60. [CrossRef]

Tsebelis, George. 2002. Veto Players: How Political Institutions Work. Princeton: Princeton University Press.

Underhill, Geoffrey. 2000. State, Market, and Global Political Economy. International Affairs 76: 805-20. [CrossRef]

Van den Hoven, Adrian. 2002. Interest Group Influence on Trade Policy in a Multilevel Polity: Analysing the EU Position at the Doha WTO Ministerial Conference. In Robert Scguman Center for Advanaced Studies EUI Working Papers 2002-67. Italy: European University Institute.

Woll, Cornelia. 2006. Trade Policy Lobbying in the European Union: Who Captures Whom? In HAL Archives Sciencepo Working Paper 06/7. Paris: CERI-Sciences Po.

Woll, Cornelia. 2007. Leading the Dance? Power and Political Resources of Business Lobbyists. Journal of Public Policy 27: 57-78. [CrossRef]

Woll, Cornelia. 2008. Firm Interests: How Governments Shape Business Lobbying on Global Trade. Ithaca: Cornell University Press.

Woolcock, Stephen. 2005. European Union Trade Policy: Domestic Institutions and Systemic Factors. In The Politics of International Trade in the Twenty-First Century: Actors, Issues and Regional Dynamics. Edited by Dominic Kelly and Wyn Grant. Basingstoke: Palgrave Macmillan, pp. 234-51.

Young, Alasdair R. 2004. The Incidental Fortress: The Single European Market and World Trade. Journal of Common Market Studies 42: 393-414. [CrossRef]

(C) 2018 by the author. Licensee MDPI, Basel, Switzerland. This article is an open access article distributed under the terms and conditions of the Creative Commons Attribution (CC BY) license (http://creativecommons.org/licenses/by/4.0/). 